\title{
Geomorphological imprint of opposing ocean bottom currents, a case study from the southeastern Brazilian Atlantic margin
}

\author{
M.M. de Mahiques ${ }^{\text {a,b, }}$, F.J. Lobo ${ }^{c}$, U. Schattner ${ }^{\mathrm{d}}$, A. López-Quirós ${ }^{\mathrm{c}}$, C.B. Rocha ${ }^{\mathrm{e}, \mathrm{f}}$, R.J.S. Dias ${ }^{\mathrm{a}}$, \\ I. Montoya-Montes ${ }^{g, h}$, A.C.B. Vieira ${ }^{a}$

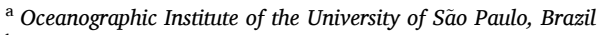 \\ ${ }^{\mathrm{b}}$ Institute of Energy and Environment of the University of São Paulo, Brazil \\ ${ }^{\mathrm{c}}$ Instituto Andaluz de Ciencias de la Tierra, CSIC-Universidad de Granada, Spain \\ ${ }^{\mathrm{d}}$ Dr. Moses Strauss Dept. of Marine Geosciences, Leon H. Charney School of Marine Sciences, University of Haifa, Israel \\ ${ }^{\mathrm{e}}$ Woods Hole Oceanographic Institution, USA \\ ${ }^{\mathrm{f}}$ presently at University of Connecticut, USA \\ ${ }^{g}$ Instituto Geológico y Minero de España, Unidad de Canarias, Las Palmas de Gran Canaria, Spain \\ ${ }^{\mathrm{h}}$ Instituto de Oceanografía y Cambio Global (IOCAG), Univ. Las Palmas de Gran Canaria, Spain
}

\section{A R T I C L E I N F O}

\section{Keywords:}

Santos Basin

Margin geomorphology

Sub-bottom profiles

Hydrodynamics

Contourites

\begin{abstract}
A B S T R A C T
The combination of oceanographic processes and a negligible fluvial terrestrial sediment contribution makes the Santos Basin margin (southwestern Brazil) a unique environment for studying thew morphological imprint of bottom currents on the seafloor morphology. We divide the seafloor into four domains: outer shelf, upper, middle, and lower slope, based on an analysis of sub-bottom Chirp profiles, multichannel seismic data, hydrographic data, numerical simulation outputs, and a seismic-derived bathymetry map. A clinoform at the outer shelf and upper slope, topped by erosional morphologies, developed below the SW-flowing Brazil Current (BC). At the bottom of the upper slope, a rugged and mounded surface around $600 \mathrm{mbsl}$ coincides with the current flow reversal to the underlying NE-flowing Intermediate Western Boundary Current (IWBC). The smooth middle slope exhibits sheeted contourites interrupted by occasional channel-and-mound complexes.

From the middle slope base, salt tectonics becomes a major player in setting the seafloor morphology. The slope-parallel Santos Channel develops above a subsurface diapir and the Cabo Frio Fault. The latter divides between the landward gap in subsurface Albian salt and the basinward rich diapir realm. Hence, the lower slope is reworked by the SW-flowing Deep Western Boundary Current (DWBC); however, salt tectonics dictates its morphology. Our study consists of a unique example for studying the morpho-sedimentary imprint of a countercurrent flowing on the continental slope and also for exploring the interaction between bottom flows with a suite of endogenic processes, such as salt tectonics, fluid flows, and mass movements.
\end{abstract}

\section{Introduction}

Oceanic thermohaline circulation mobilizes water masses via currents (e.g., Viana et al., 2002). In places where the oceanic circulation flows along a continental margin, the friction of bottom currents with the seabed produces strike-parallel depositional and/or erosional contourite morphologies, which direct the flow of bottom currents (e.g., Rebesco et al., 2014). This connection between the seafloor morphology and the pattern of bottom current flows makes the relief of a continental margin an indicator for past oceanic flows and hence a proxy for past thermohaline circulation (e.g., Stow et al., 1998; Wilckens et al., 2021).
This cause-effect feature occurs particularly in places where down-slope processes, such as sediment flows from terrestrial rivers, slope canyons, and slides (e.g., Shanmugam, 2017), are subdued or ancillary to alongslope processes.

The Atlantic margins of South America bound the South Atlantic circulation and are influenced by western boundary currents (Boebel et al., 1999). Many of these margins are sediment starved and affected by diverse water masses flowing at different depth intervals that generate depth-restricted contourite morphologies and deposits. Notable cases of such contourite environments include the Demerara Plateau off French Guiana (Tallobre et al., 2016), the northeastern

\footnotetext{
* Corresponding author.

E-mail address: mahiques@usp.br (M.M. de Mahiques).
} 
Brazilian margin (Gomes and Viana, 2002), the southeastern Brazilian margin in Campos and Santos basins (Fig. 1a; Viana et al., 1998a, 1998b; Viana et al., 1998a, 2002a, 2002b; Viana, 2001; Schattner et al., 2020) and the Uruguayan-Argentinian margin (e.g., Hernandez-Molina et al., 2009, 2010, 2015; Preu et al., 2012; Wilckens et al., 2021). Sediment drifts also formed at abyssal depths, below flows of the Atlantic and Antarctic water masses (e.g., (Viana et al., 1998a,b), 2001; Faugères et al., 2002).

The seabed morphology consists mainly of contourite geometries with moderate to reduced fluvial input. Geomorphological variations occur mainly associated with water masses interfaces (e.g., Preu et al., 2013; Hernández-Molina et al., 2016). Additionally, long-term climatic variability (i.e., glacial-interglacial) may alter the vertical extent of depth intervals influenced by specific water masses. Consequently, the geomorphological imprints of associated bottom currents may change spatially (e.g., Viana et al., 1998a,b; Hernández-Molina et al., 2016). Finally, other deep-rooted seafloor morphologies, such as pockmarks, slide scars, faults, and surface expressions of salt structures, also detour and guide seafloor currents (Stow et al., 2008; Rebesco et al., 2014; Schattner et al., 2018).

The large-scale circulation of the southeastern Brazilian margin has a unique vertical structure. In this sector, the intermediate water mass is transported opposite to both shallower and deeper currents (Fig. 1a) (Boebel et al., 1999; Schmid et al., 2000). The opposing direction stems from differences between the wind-driven Subtropical Gyre and Meridional Overturning Circulation in the South Atlantic (Stramma and England, 1999). North of $28^{\circ} \mathrm{S}$, the Intermediate Western Boundary Current (IWBC) flows northwards, between the southward flows of the shallow Brazil Current (BC, above) and Deep Western Boundary Current (DWBC, below) (Biló et al., 2014).

This study analyzes the outer shelf to lower slope relief and subsurface of the Santos Basin sector north of $28^{\circ} \mathrm{S}$ (Fig. 1b). This study integrates observations from shallow-water shelf to deep-water slope settings, highlighting the downslope spatial variability between shallow-water and deep-water contourite depositional systems. The knowledge of contourite patterns in this margin sector is relevant since it offers us a unique opportunity to understand the morpho-sedimentary response of an intermediate current flow moving in the opposite direction to the upper and lower southward-moving water flows, thus providing a world-class example that could be used for reconstructing paleo-oceanographic conditions. The counter-current mid-water flow also triggers the occurrence of quasi-zero flows in an extensive acrossmargin section. Consequently, the influence of bottom currents may be subdued in wide areas of the margin, and in contrast, their interaction with diverse endogenic processes such as salt tectonics, fluid flows, and mass movements can be enhanced. This pattern markedly contrasts with other contourite settings, where current patterns tend to flow in the same direction, and energetic oceanographic phenomena tend to be limited to water mass interfaces (e.g., Preu et al., 2013; Hanebuth et al., 2015). Therefore, the study area can be regarded as a prime example of a contouritic environment with strong interactions with a range of subsurface and shallow processes, resulting in complex deep-water sedimentation patterns.

Considering those previous considerations, we define and characterize contourite features between $\sim 100-2000 \mathrm{~m}$ water depths and explore their vertical and lateral variability. We aim to derive present and past morphological current indicators, assuming that the negligible fluvial input (Schattner et al., 2018) emphasizes the overwhelming control of strike-parallel bottom currents on the seabed morphology. We hypothesize that the unique water column structure, including the different interfaces between water masses and specifically the transition, bends between opposing flows, should be expressed in the seafloor morphology and its subsurface. Ultimately, we discuss the importance of driving contourite variability factors in each margin's physiographic domain, from the outer shelf to the lower slope.

\section{Study area}

The study area includes the outer shelf and upper to middle slope of the Santos Basin, off São Sebastião Island (SE Brazil), between $23.25^{\circ} \mathrm{S}$ $26.92^{\circ} \mathrm{S}$ and $43.08^{\circ} \mathrm{W}-45.76^{\circ} \mathrm{W}$ (Fig. 1 ).

\subsection{Geological setting}

The $350,000 \mathrm{~km}^{2}$ Santos Basin extends east of the tectonically passive Santos margin (Fig. 1). It is delimited by the Florianópolis High (FH) to the south, the Cabo Frio (CF) to the north, the Serra do Mar Mountain range to the west, and the São Paulo Plateau to the east (Gamboa and Rabinowitz, 1981; Hung Kiang et al., 1992). The present-day morphology of the Santos Basin seafloor results from the combination
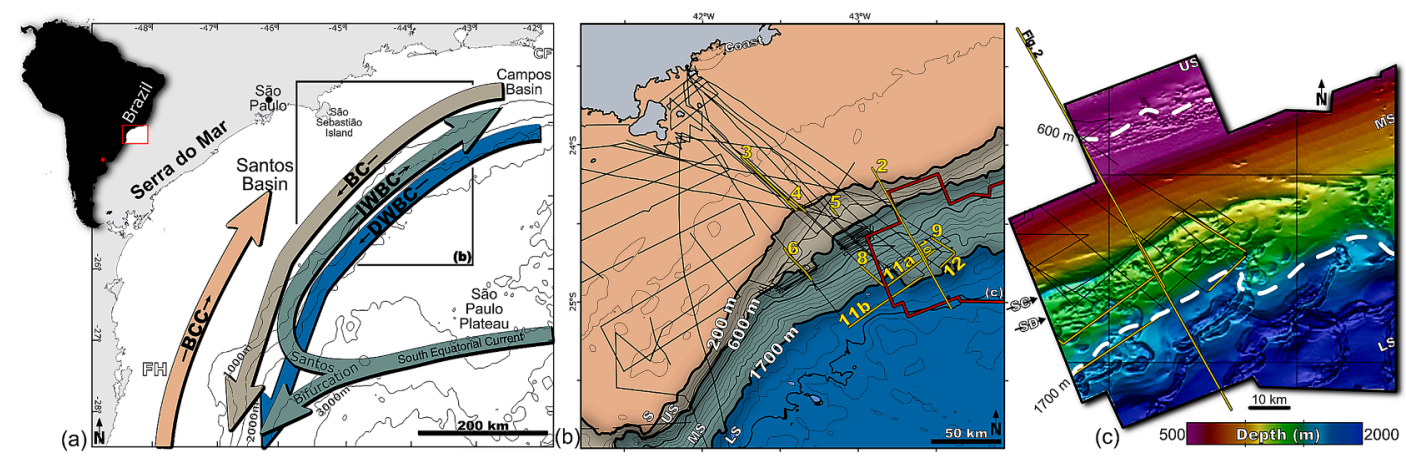

Fig. 1. Location of the study area and geophysical database. (a) Scheme of major currents flowing along Santos Basin. BCC-Brazilian Coastal Current; BC-Brazil Current; IWBC-Intermediate Western Boundary Current; DWBC-Deep Western Boundary Current. CF-Cabo Frio; FH-Florianópolis High. The black box marks the location of (b). Isobath contours were extracted from ETOPO-1 in a 500 m interval (Amante and Eakins, 2009; NOAA, 2009).

(b) Location of single-channel $3.5 \mathrm{kHz}$ Chirp seismic lines obtained in different surveys onboard R/V Alpha Crucis between 2013 and 2017 in the study area (black lines, also in (c)). Yellow lines mark the location of seismic lines presented in the following figures with yellow figure numbers (also in (c)). Yellow line number 2 marks the location of a multichannel seismic reflection line provided by the National Agency of Oil, Natural Gas, and Biofuels (Fig. 2). Red polygon marks the location of the bathymetric map presented in (c). Isobath contours were extracted from Global Multi-Resolution Topography in $100 \mathrm{~m}$ intervals (Ryan et al., 2009). Thick black contours of 200, 600, and $1700 \mathrm{~m}$ mark the transition between the bathymetric domains: Shelf (S), Upper Slope (US), Middle Slope (MS), and Lower Slope (LS). Coloring of the domains corresponds to the depth range of currents depicted in (a).

(c) Bathymetric map derived from interpretation of seismic reflection data (after Guerra and Underhill, 2012), extending across the upper, middle, and lower slope domains (US, MS, LS, respectively). Thick dashed lines mark the water mass interfaces at 600 and 1700 mbsl. SC-Santos Channel, SD-Santos Drift. Interpretation of this map appears in Fig. 7. (For interpretation of the references to colour in this figure legend, the reader is referred to the web version of this article.) 
of tectonic inheritance, Paleogene-Neogene halokinetic activity, late Quaternary sea-level changes, sediment reworking by bottom currents (de Mahiques et al., 2004; Guerra and Underhill, 2012; Reis et al., 2013), and downslope processes that occur in the southwestern Atlantic margin (Steventon et al., 2020).

The Santos basin began to open during the first tectonic pulses that led to the Gondwana supercontinent breakup during the Neocomian (Cainelli and Mohriak, 1999). Its initial rifting during the Barremian was followed by widespread salt and carbonate production from late Aptian to early Albian. The massive salt layer constituted a detachment level for pervasive halokinesis (Fig. 2) (e.g., Butler, 1970; Williams and Hubbard, 1984; Alves et al., 2017).

The drift phase started during the Albian, with the progressive submergence of the previous Santos margin and its carbonate platform (Mohriak et al., 1995). The continuous subsidence of the basin was accompanied by a massive transfer of continental sediments from the late Cretaceous until the Oligocene when the drainage systems of SE Brazil were reorganized after the uplift of the Serra do Mar mountain range (Almeida and Carneiro, 1998; Meisling et al., 2001; Modica and Brush, 2004; Cogné et al., 2012).

Intensive Cenozoic salt tectonics deformed the Aptian evaporitic deposits. Lateral salt flow formed the 'Albian gap' in the salt unit, extending basinward to the Cabo Frio Fault (CFF in Fig. 2b). The flow was accompanied by the formation of overlaying rollover Cretaceous monoclines above the depleted salt area of the 'Albian Gap' and intense diapirism east of it, in the deeper basin(Fig. 2) (Modica and Brush, 2004; Guerra and Underhill, 2012). Salt tectonics has continued to influence the slope morphology until the present (de Mahiques et al., 2017; Schattner et al., 2018).

The modern shelf architecture started to develop in the middle Miocene, bounded by narrow coastal plains and small riverine systems that drain Precambrian crystalline rocks (Kowsmann and Costa, 1979; Zembruscki, 1979; Zalan and Oliveira, 2005). The paucity of fluvial input deprived the shelf from terrestrial contribution, while the input transported by the along-margin circulation (especially the $\mathrm{BC}$ ) remained high (Schattner et al., 2020).

\subsection{Physiography and sedimentation of the upper margin of Santos Basin}

Shelf width varies largely along the Brazilian margin within the study area (Fig. 1). Close to Cabo Frio, the shelf is about $70 \mathrm{~km}$ wide. Off the city of Santos, the width reaches about $230 \mathrm{~km}$, representing one of the largest shelf areas of the whole SW Atlantic (Figueiredo and Tessler, 2004). The shelf break is located between 120 and $180 \mathrm{~m}$, the deeper

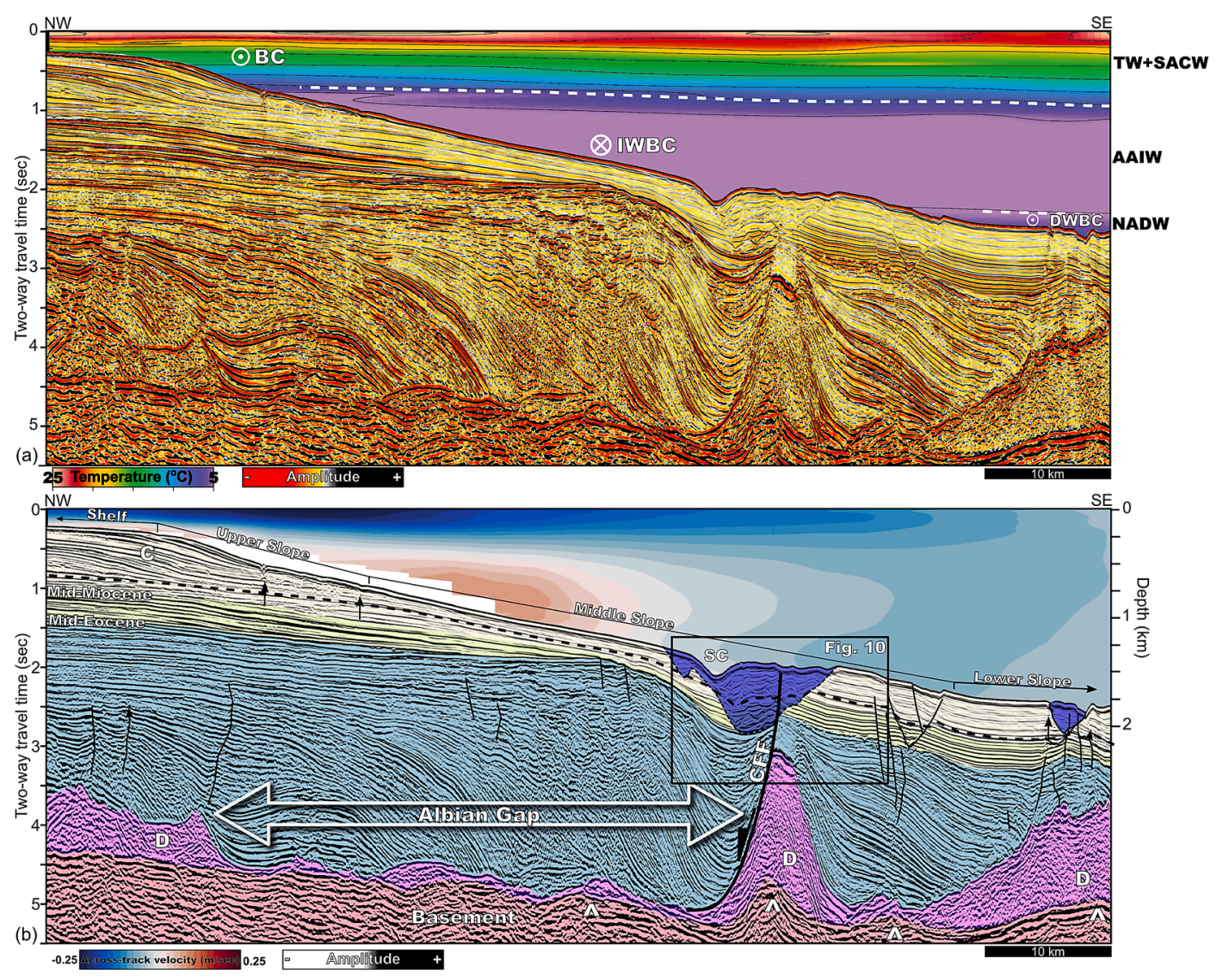

Fig. 2. (a) A SE-trending time-migrated multichannel seismic reflection profile crossing the distal margin of the Santos Basin (location in Fig. 1). Data is presented in the amplitude attribute that went through structural smoothing. A hydrographic temperature panel is presented above the seismic data showing the main water masses and currents, divided by thick dashed white lines. BC-Brazil Current; IWBC-Intermediate Western Boundary Current; DWBC-Deep Western Boundary Current; TW-Tropical Water; SACW-South Atlantic Central Water; AAIW-Antarctic Intermediate Water; NADW-North Atlantic Deep Water.

(b) Same seismic profile as above, presented in black and white, overlayed by simplified interpretation, after Guerra and Underhill (2012) and Quirk et al. (2012). Shading: red-basement, pink-Aptian salt, light blue-Cretaceous-mid Eocene, green-mid-Eocene-mid-Miocene, light beige-mid-Miocene-recent. A thick dashed black line marks the Miocene clinoform initiation (C) below the Outer Shelf and Upper Slope (S, US, respectively), thinning under the Middle Slope (MS), and thickening under the Lower Slope (LS). Purple shading marks the fill of margin-parallel contourite systems, which include the Santos Channel (SC). Note the spatial association of SC, a subsurface diapir (D), and the Cabo Frio Fault (CFF), which bounds the Albian gap (e.g., Quirk et al., 2012). Thin black lines mark possible subsurface faults; black arrows mark possible fluid paths. The black box marks the location of detailed interpretation presented in Fig. 9. The seismic data is topped by the across-track velocity field of the water column based on the LLC2160 model. (For interpretation of the references to colour in this figure legend, the reader is referred to the web version of this article.) 
being associated with broader shelf sectors (Zembruscki, 1979).

The Santos continental slope extends over $79,000 \mathrm{~km}^{2}$ with a smooth morphology and declivity varying from $1^{\circ}$ to more than $2^{\circ}$ (Milliman, 1978). The slope steepens around the $1000 \mathrm{~m}$ isobath (Fig. 1b). Its base occurs between 1800 and $2200 \mathrm{~m}$, becoming shallower toward the north of Santos Basin (Figueiredo and Tessler, 2004).

The slope contains two major along-slope channels (Duarte and Viana, 2007). The Santos Channel runs parallel to the slope along the $1500-\mathrm{m}$ isobath (Fig. 1). This channel is about $2 \mathrm{~km}$ wide and $100 \mathrm{~m}$ deep, extending over more than $200 \mathrm{~km}$. It is embedded in the Cabo Frio Fault (Demercian et al., 1993; Szatmari et al., 1996). The 4500-m deep São Paulo Channel is $15-20 \mathrm{~km}$ wide and $300 \mathrm{~m}$ deep and marks the passage with the São Paulo Plateau (Duarte and Viana, 2007; Perez et al., 2020), a deep marginal elevation underlain by oceanic crust and bounded by fracture zones (Butler, 1970; Kumar and Gambôa, 1979). Below 1500-1800 m deep, pervasive halokinesis formed a puzzling pattern of small basins, topographic highs, and salt diapir exhumations (Moreira et al., 2007; Caldas and Zalán, 2009).

The sedimentary growth of the continental shelf and the upper slope has been guided by the deposition of offlapping forced-regressive wedges locally molded by escarpments attributed to the erosional activity of the BC (Reis et al., 2013). Recent sedimentation processes exhibit a well-defined boundary at the location of São Sebastião Island (SSI in Fig. 1a). South of the island, sediments are mostly derived from La Plata river runoff and transported by the Brazilian Coastal Current (de Mahiques et al., 2004; Souza and Robinson, 2004). Southeast of the island, sedimentation processes on the mid to outer shelf are mainly influenced by the BC meanders, whose activity has guided sediment transport processes and the development of bedforms (Dias de Araujo et al., 2021). Extensive reworking of the outer shelf by the BC (Fig. 1a) promotes the export of coarse-grained sediments toward the slope via gravity flows (Viana et al., 1998a, b; de Mahiques et al., 2011). Deeper strike-parallel currents carry this supply to form channel-related contourite drifts, like the Santos Drift over the middle slope and the São Paulo Drift at depths higher than $2000 \mathrm{~m}$ These drifts mainly developed during highstand stages due to circulation intensification (Duarte and Viana, 2007).

\subsection{Physical oceanography}

The water column is stratified into three layers, confined between specific depth intervals (Fig. 2). The upper layer is characterized by temperatures higher than $10^{\circ} \mathrm{C}$, attributed to the South Atlantic Central Water (SACW). The temperatures decrease to $\sim 8{ }^{\circ} \mathrm{C}$ at the lower boundary, $400 \mathrm{~m}$ below sea level (mbsl). Below, the middle layer exhibits homogeneous temperatures of $6{ }^{\circ} \mathrm{C}$. Its depth range (450-1500 mbsl) corresponds to the Antarctic Intermediate Water (AAIW). Below $1500 \mathrm{mbsl}$, the lower layer exhibits a temperature lower than $5{ }^{\circ} \mathrm{C}$, corresponding to the transition to the North Atlantic Deep Water (NADW). The motion of these water masses is determined by the western branch of the South Atlantic Subtropical Gyre and its interaction with the global overturning circulation (Fig. 1a) (Peterson and Stramma, 1991; Stramma and England, 1999). This circulation system comprises the BC, which transports Tropical Water (TW) and South Atlantic Central Water (SACW) in the upper $500 \mathrm{~m}$ (Silveira et al., 2004) (Fig. 2). The BC flows southwestwards along the outer shelf and upper slope with maximum speeds of up to $0.6 \mathrm{~m} \mathrm{~s}-1$ (Biló et al., 2014); it is intensified south of $24^{\circ} \mathrm{S}$ due to the contribution of recirculation cells (Stramma and England, 1999). Along the Santos and Pelotas basins, the BC is prone to strong meandering and eddy shedding, and these features are associated with a southward increase in eddy kinetic energy (Fernandes et al., 2009; Assireu et al., 2017; Magalhães et al., 2017). The meandering pattern of the $\mathrm{BC}$ is evidenced by the occurrence of seawarddirected bedforms indicating the direction of sediment transport, suggesting sediment export from the shelf to the slope. Also, the erosional power of the $\mathrm{BC}$ was already confirmed in previous studies by Viana et al. (1998a), de Mahiques et al. (2004), and Dias de Araujo et al. (2021), among others. Landward of the BC, the shelf is episodically swept by the northward-moving Brazilian Coastal Current (BCC in Fig. 1a; Souza and Robinson, 2004).

At intermediate bathymetric levels, between 500 and $1200 \mathrm{~m}$ water depths, the South Equatorial Current (the return current of the South Atlantic Subtropical Gyre) reaches the continental slope in the Santos Plateau, where it bifurcates (i.e., the Santos Bifurcation; Núñez-Riboni et al., 2005; Legeais et al., 2013). Close to the margin, at $\sim 28^{\circ} \mathrm{S}$, this current splits. Its northern branch, the IWBC, flows northeastwards at $0.20-0.30 \mathrm{~m} \mathrm{~s}^{-1}$ along the $800 \mathrm{~m}$ isobath, mainly transporting the AAIW (Boebel et al., 1999; Silveira et al., 2004; Fernandes et al., 2009; Legeais et al., 2013) (Fig. 2). Underneath, the Deep Western Boundary Current (DWBC) flows southwards, carrying the NADW (Stramma and England, 1999), with a core velocity of about $0.1 \mathrm{~m} \mathrm{~s}^{-1}$ (Müller et al., 1998).

\section{Database and methodology}

Three types of data were used in this study. A bathymetric map from Guerra and Underhill (2012) was used to define physiographic domains, their boundaries, and various geomorphological features. The map is based on the interpretation of dense three-dimensional seismic data. Seismic reflection data were used for characterizing recent (Chirp subbottom profiles) and older (multichannel) subsurface sedimentary architecture. Hydrographic data and outputs of numerical models were used to depict the oceanographic patterns in the study area.

\subsection{Seismic reflection data}

About $1900 \mathrm{~km}$ of $3.5 \mathrm{kHz}$ sub-bottom profiling were acquired onboard RV Alpha Crucis in several cruises conducted from 2013 to 2017 (black lines in Fig. 1b). A 2 kW Knudsen 3260 Chirp Sub-bottom Profiler, with a $27^{\circ}$ wide-angle and $3.5 \mathrm{kHz}$ transducer, was used during these surveys. We assume an average value of $1500 \mathrm{~m} \mathrm{~s}^{-1}$ for sediment sound velocity to estimate depths and sediment thickness. All seismic data were recorded in raw format and subsequently transformed in SEG-Y format. Post-processing included wave correction filtering in RadExPro (Deco Geophysical Software Company) and MDPS (Meridata Finland).

Several time-migrated multichannel seismic reflection lines crossing the study area were provided by the Brazilian Petroleum, Natural Gas and Biofuels Agency (ANP) for academic use. From these data, we present one dip line that crosses the morphologic domains and the Santos Channel (Figs. 1, 2). The seismic data were collected as part of a regional survey within the Santos Basin and margin, in a two-second sample interval and record length of $12 \mathrm{~s}$. The was collected using 324 channels and filtered to exclude frequencies exceeding the $5-206 \mathrm{~Hz}$ range. The data went through standard processing, including resampling to $4 \mathrm{msec}$, frequency and swell filtering and attenuation, deconvolution, and prestack time migration. Interpretation of the major geological units was based on Guerra and Underhill (2012) and Quirk et al. (2012). The subsurface acoustic facies were interpreted based on existing schemes for the classification of contouritic sedimentation, both in shallow water (Verdicchio and Trincardi, 2008) and in slope settings (HernándezMolina et al., 2008; Rebesco et al., 2014).

\subsection{Oceanographic dataset and circulation model characterization}

Temperature and hydrographic panels were constructed above the selected multichannel seismic line to highlight the water column structure (Fig. 2). The panels were extracted from the World Ocean Database (Locarnini et al., 2018) using the Ocean Data View software ${ }^{\mathrm{TM}}$ (ODV, 2020).

To characterize the background circulation in the region, we use the LLC2160 simulation, a $1 / 24^{\circ}$ Massachusetts Institute of Technology General Circulation Model (MITgcm) simulation on a Latitude 
Longitude Polar Cap (LLC) grid. The LLC2160 simulation is part of the "Estimating the Circulation and Climate of the Ocean" (ECCO) project (e.g., Menemenlis et al., 2008). This project makes optimal global "ocean estimates" using a combination of MITgcm simulations and an array of observations, including Argo profiles, moorings arrays, and satellite altimetry. The baseline ECCO Phase II state estimation was run from 1992 to 2012 (see details in Menemenlis et al., 2008). The LLC2160 simulation is a forward integration spun up from the LLC1080 solution, which in turn was spun up from the January 2010 ECCO Phase II ocean estimate and run for 27 months. This hierarchy of spin-ups is described in the online supplementary material of Rocha et al. (2016). The LLC2160 vertical and horizontal resolutions of 90 depth levels and about $4 \mathrm{~km}$ are critical to representing the details of the boundary currents in the Brazilian Continental Margin.

For our analysis, we discard the first three months of the LLC2160 output to avoid contamination associated with the spin-up of submesoscale flows, which are not resolved in the LLC1080 simulation but are permitted by LLC2160's high resolution. The velocity field discussed below is a two-year average spanning April 2011 through April 2013. It represents an annual-mean view of the regional circulation, excluding the higher-frequency flows. The mean horizontal velocities were interpolated onto the cross-slope section using the nearest neighbor method (Fig. 2b).

\section{Results}

\subsection{Seafloor morphology and sub-bottom acoustic facies}

Data exhibits four morphological domains across the 100-2000 mbsl depth range: outer shelf, upper slope, middle slope, and lower slope (Figs. 1, 2). These domains are bounded by marked geomorphological boundaries.

\subsubsection{Outer shelf (100-200 mbsl)}

Multichannel seismic reflection data below the outer shelf shows seaward prograding sigmoid clinoforms (' $\mathrm{C}$ ' in Fig. 2b). Sub-bottom profiles indicate that the outer shelf is bounded landward by a $\sim 20$ m-high escarpment ( $\sim 200 \mathrm{mbsl}$; Figs. 3,4$)$. The outer shelf shows a minimal variability in the average seafloor gradients $\left(0.02-0.13^{\circ}\right)$ and an irregular relief. Subsurface data exhibit progradational patterns (Fig. 3b) truncated by a flat erosional surface (Figs. 3b, 4). A $\sim 8 \mathrm{~km}$ wide concave depression occurs seaward from the mid-shelf escarpment (Fig. 3b). Further basinward, seafloor mounds with high reflectivity appear between 140 and $150 \mathrm{~m}$ water depths (yellow rhombi in Fig. 3b). Their width ranges between tens of meters to more than a kilometer, their tops stand several meters above the surrounding seabed, and their profile is mostly asymmetric with a steeper seaward face. Due to the limited extent of the 2D data, it was not possible to map the lateral extent of the mounds and the concave depression.

The seafloor smoothens and steepens $\left(>0.3^{\circ}\right)$ between the mounds and the shelf break, where the acoustic penetration is low (less than 10 m) (Fig. 3a). An SW-NE trending escarpment occurring at $165 \mathrm{mbsl}$ appears as a channel at $175 \mathrm{mbsl}$. The channel is up to $500 \mathrm{~m}$ wide and $14 \mathrm{~m}$ deep, increasing its dimensions toward the southwest. The channel exhibits an asymmetric profile, with a steep $9.6^{\circ}$ landward flank and a convex $0.8^{\circ}$ seaward flank. Both flanks truncate their underlying reflections (Fig. 4).

\subsubsection{Upper slope (200-600 mbsl)}

Multichannel data show that the upper slope comprises the toe of the clinoform (Fig. 2b). The upper slope exhibits seaward variations in steepness: $0.55^{\circ}$ between $\sim 200-250 \mathrm{mbsl}$; between 250 and $420 \mathrm{mbsl}$, the gradient steepens to $1.2^{\circ}$ in the southwest and $1.5^{\circ}$ in the northeast; and moderates to $0.7^{\circ}$ seawards, deeper than $420 \mathrm{mbsl}$. Off the shelf break, the seafloor exhibits an irregular morphology (Fig. 4). The erosional truncation extends seaward down to $250 \mathrm{mbsl}$ (yellow arrows in Fig. 4), accompanied by localized smooth depressions. In the shallow subsurface, low-angle parallel oblique reflections appear down to 350 mbsl (Fig. 4).

A $230 \mathrm{~m}$ wide and $6 \mathrm{~m}$ deep channel occurs at around $250 \mathrm{mbsl}$ (Figs. 4c). The declivity of its flanks is $\sim 3.0^{\circ}$ and $1.7^{\circ}$ (upslope and down-slope, respectively). The channel deepens northeastward across the study area from 225 to $280 \mathrm{mbsl}$. In the subsurface, a few wider $(\sim 1$ $\mathrm{km}$ ) infilled paleochannels occur seaward (Fig. 4c). Their infill exhibits two distinct facies divided by an irregular erosional truncation: highamplitude sub-parallel lower facies and low-reflectivity upper facies.

The upper slope relief smoothens between 300 and $600 \mathrm{mbsl}$, where its average gradient is $0.74^{\circ}$. The upper tens of meters exhibit a lowreflectivity acoustic response in the subsurface, becoming stratified below (Fig. 5). Single-channel data show basinward thinning of the clinoform layers that downlap to the southeast (Figs. 5, 6). The thinning trend is represented in the data by tree subsurface undulating layers (Fig. 5). The upper layer 1 thins by $73 \%$, layer 2 by $84 \%$, layer 3 by $47 \%$, over a distance of $\sim 5.5 \mathrm{~km}$. The undulations of layer 3 increase downslope. Similar thinning appears at the equivalent water depths presented in Fig. 6 (yellow rectangles). The distal boundary of the upper slope is marked by a break of the continental slope at 600 mbsl (Figs. 6, 7) that exhibits a rugged bathymetry with numerous small-scale depressions and localized chaotic reflectivity above and below the seafloor (pink shading in Fig. 6c). The multichannel indicates localized depressions

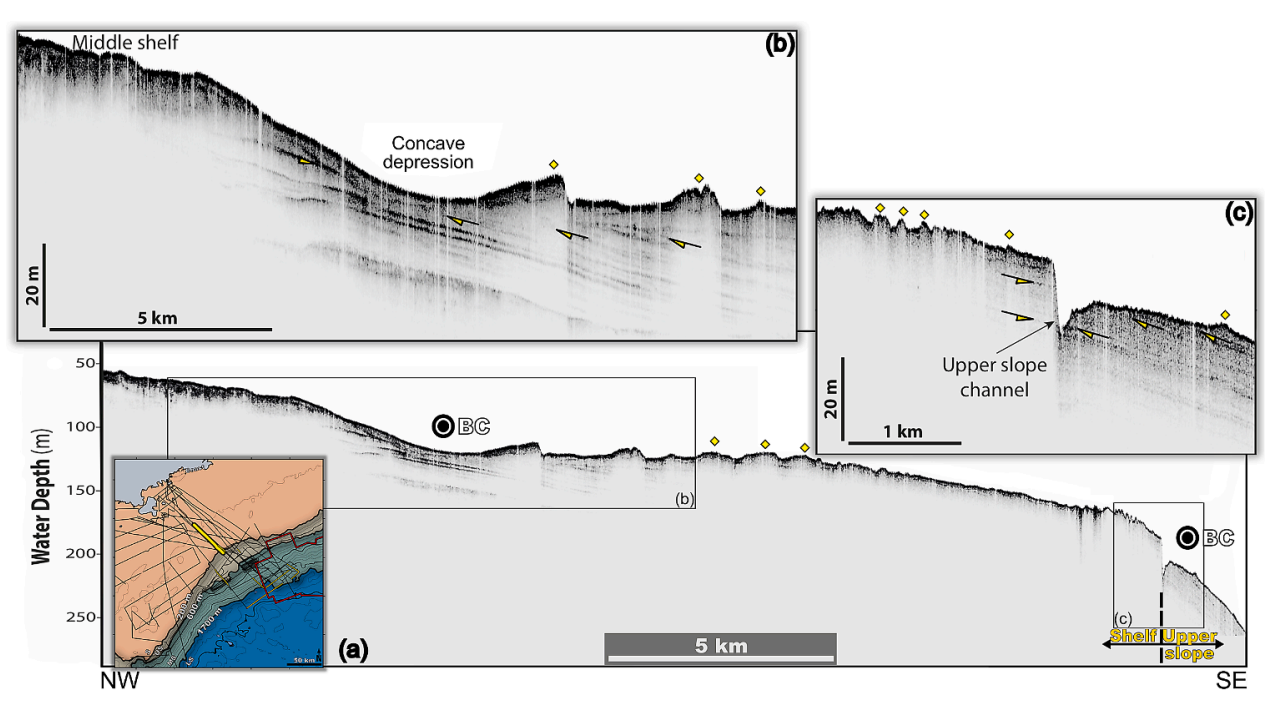

Fig. 3. (a) Chirp sub-bottom profile representative of the transition between the (b) shelf and (c) upper slope. The transition is marked by a surface escarpment marked as "upper slope channel". The shelf exhibits an erosional surface (above the yellow arrows) and asymmetric seafloor mounds (yellow rhombi). Location of the profile is highlighted in yellow in the inset map. The Brazil Current (BC) flows southwestward over both domains. (For interpretation of the references to colour in this figure legend, the reader is referred to the web version of this article.) 

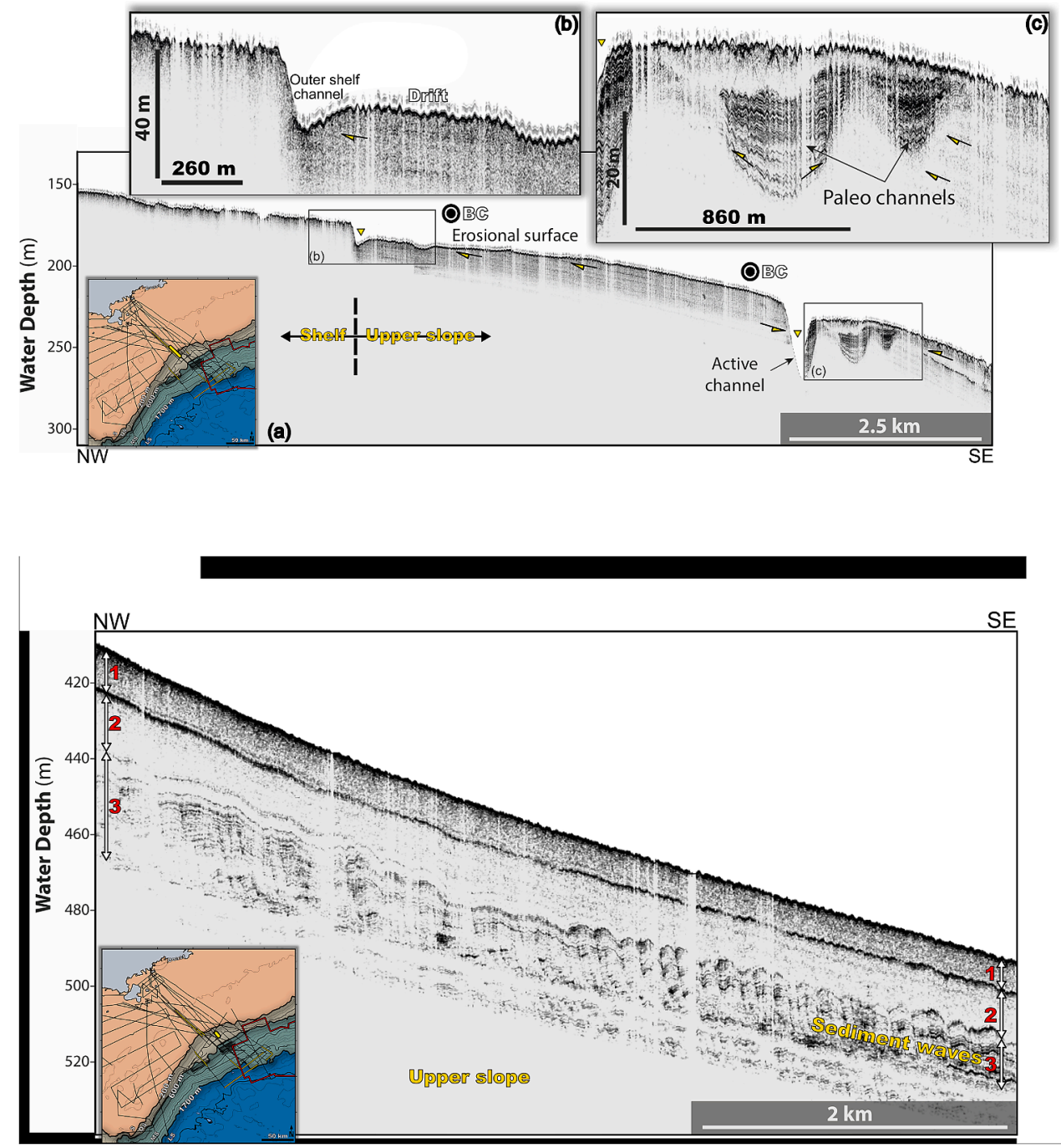

Fig. 4. (a) Chirp sub-bottom profile crossing the shelf to upper slope transition. Yellow triangles mark seafloor channels. (b) Surface depression represents an outer shelf channel and an adjacent drift deposit. (c) A complex of two paleochannels at the upper slope adjacent to an active seafloor channel. Up-facing yellow arrows mark onlap, down-facing arrows mark truncated layers. Location is highlighted in yellow on the inset map and Fig. 1b. (For interpretation of the references to colour in this figure legend, the reader is referred to the web version of this article.)
Fig. 5. Chirp sub-bottom profile from the upper slope in the study area, showing a smooth seafloor underlain by three undulating subsurface layers that thin downslope: layer one by $73 \%$, layer two by $84 \%$, layer three by $47 \%$. Layer 3 exhibits sediment waves with decreasing wavelength upslope and into the overlying layer 2. Location is highlighted in yellow on the inset map and Fig. 1b. (For interpretation of the references to colour in this figure legend, the reader is referred to the web version of this article.)

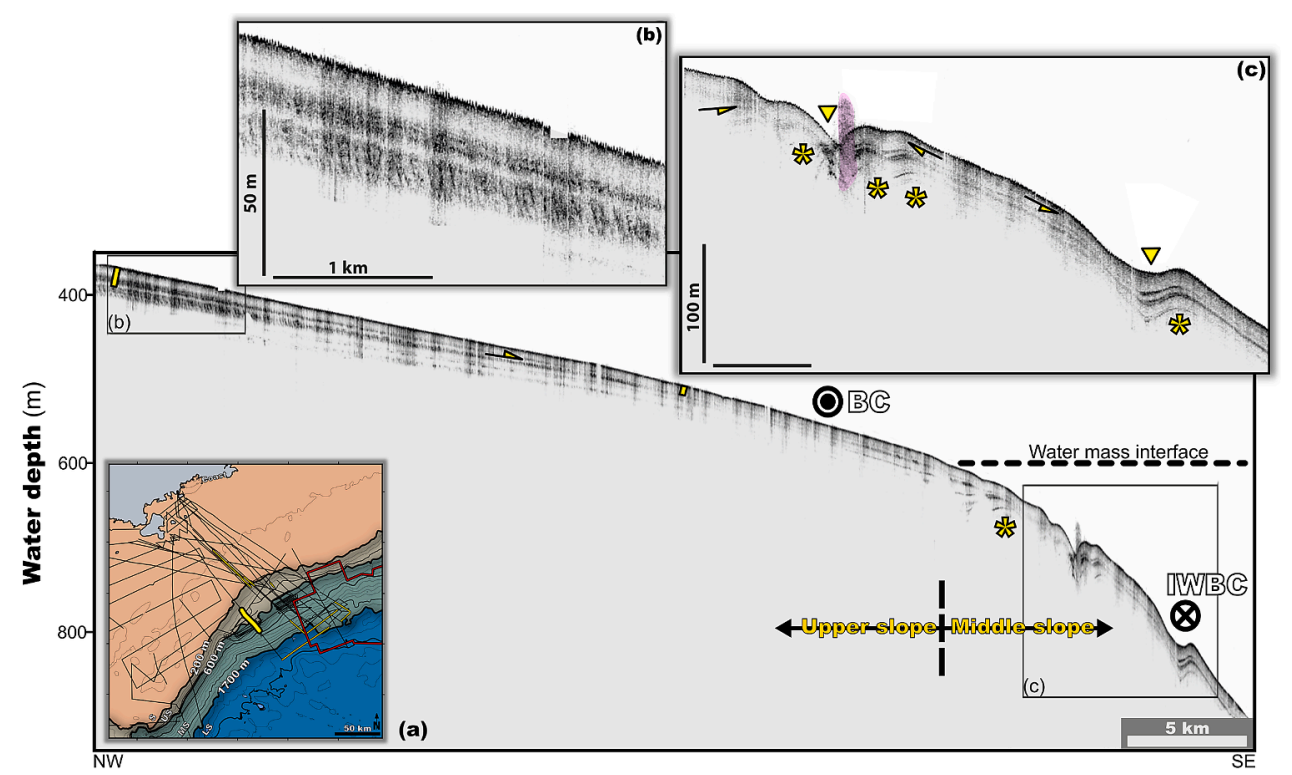

Fig. 6. (a) Chirp sub-bottom profile covering the transition from the upper to the middle slope, marked by an increase in slope gradient. The upper slope exhibits sub-parallel reflections (also in (b)) that thin toward the middle of the profile in the SE, as indicated by two yellow rectangles. Truncation of these upper reflectors suggests the thinning results from erosion at the seafloor, under the flow of the Brazil Current (BC). A dashed horizontal black line marks the water mass interface. The middle slope (also in (c)) exhibits surface depressions (yellow triangles) associated with adjacent seafloor mounded patterns (yellow asterisks). Pink shading in (c) marks a possible gas/fluid escape feature. The Intermediate Water Boundary Current (IWBC) flows northeastward over the middle slope domain. Upfacing yellow arrows mark downlap, downfacing arrows mark truncated layers. Location is highlighted in yellow on the inset map and Fig. 1b. (For interpretation of the references to colour in this figure legend, the reader is referred to the web version of this article.) 


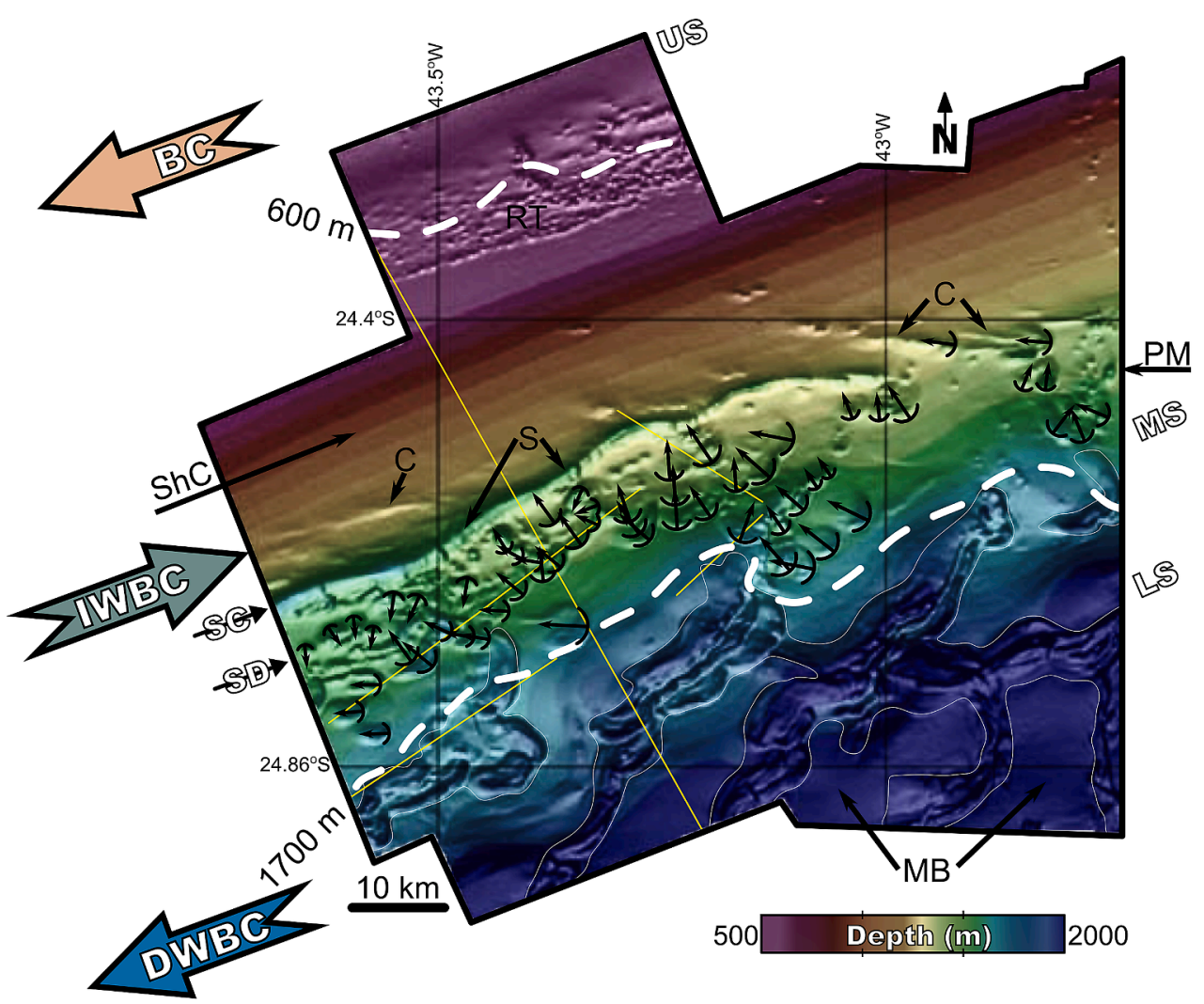

Fig. 7. Interpretation of the seismic-derived seafloor bathymetry (after Guerra and Underhill, 2012). The upper to middle slope transition exhibits a rugged terrain (RT); seaward, a smooth slope, is interrupted by occasional elongated channels (C). The Santos Channel (SC) establishes the boundary with the lower slope. Localized slides (S) appear on the SC flanks, tangent to its thalweg. The elongated bulge of the Santos Drift (SD) includes numerous localized arc-shaped rotational slide scars marked by coupled black arcs and arrows (marking the slide direction). The lower slope (LS) seaward of the SD exhibits a smoother relief divided into mini-basins (MB) by elongated valleys (bounded by thin white lines) topping subparallel extensional faults (see Fig. 10). Thin yellow lines represent the location of the seismic profile presented in previous figures. Location of the seafloor bathymetry appears in Fig. 1b. (For interpretation of the references to colour in this figure legend, the reader is referred to the web version of this article.) and subsurface smearing (vertical black arrows below the upper slope in (Fig. 2b).

\subsubsection{Middle slope (600-1700 mbsl)}

The middle slope extends seaward from the $600 \mathrm{mbsl}$ slope break (Figs. 6, 7), with average seafloor gradients that steepen from $\sim 1.3^{\circ}$ in the NE to $\sim 1.55^{\circ}$ in the SW, attaining a maximum value of $2.2^{\circ}$. The seismic-derived bathymetry map indicates that the middle slope relief is generally smooth down to the Santos Channel (SC in Fig. 7). Elongated seafloor depressions ( $\mathrm{C}$ in Fig. 7) accompanied by mounds in their downslope flanks are observed between 600 and 840 mbsl (Figs. 6, 7). These depressions are up to $20 \mathrm{~m}$ deep and $\sim 100 \mathrm{~m}$ wide. They overlay a succession of similar depression-mound couples in the subsurface (Fig. 6c). Another set of elongated depressions with higher reliefs is observed between 1200 and $1450 \mathrm{mbsl}$, almost coincidentally with a seafloor steeping below 1300 mbsl (Figs. 8, 9). The bathymetric map shows that these depressions extend from parallel to oblique to the margin (Fig. 7). Most of the depressions exhibit progressive, asymmetric infillings (Figs. 8 and 9), and as a consequence, their morphological expression becomes subdued up-section (Yellow triangles in Fig. 8). Flat morphologies underlay by continuous sub-parallel reflections divide between these channels (Drift in Fig. 8).

The distal boundary of the middle slope is marked by the Santos Channel (SC in Fig. 7), characterized by a southwestward thalweg

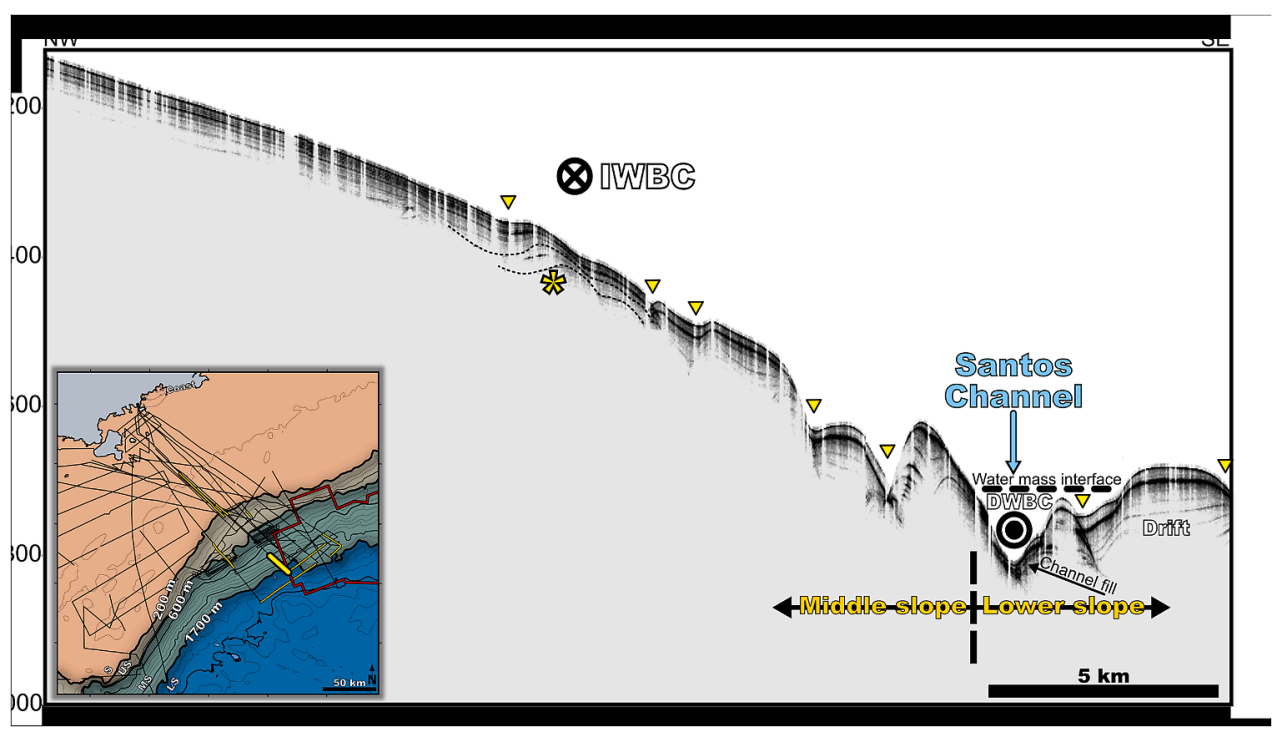

Fig. 8. Chirp sub-bottom profile showing the boundary from the middle to the lower slope and establishing the depth of occurrences of the IWBC and the DWBC (Deep Water Boundary Current). Yellow triangles mark seafloor depressions, yellow asterisks, and dashed lines mark their associated subsurface mounded reflections. The transition between the middle to the lower slope is marked by a pronounced depression (Santos Channel) and associated sediment mound (Santos Drift) (also see Figs. 1c and 12). Location is highlighted in yellow on the inset map and Fig. 1b. (For interpretation of the references to colour in this figure legend, the reader is referred to the web version of this article.) 


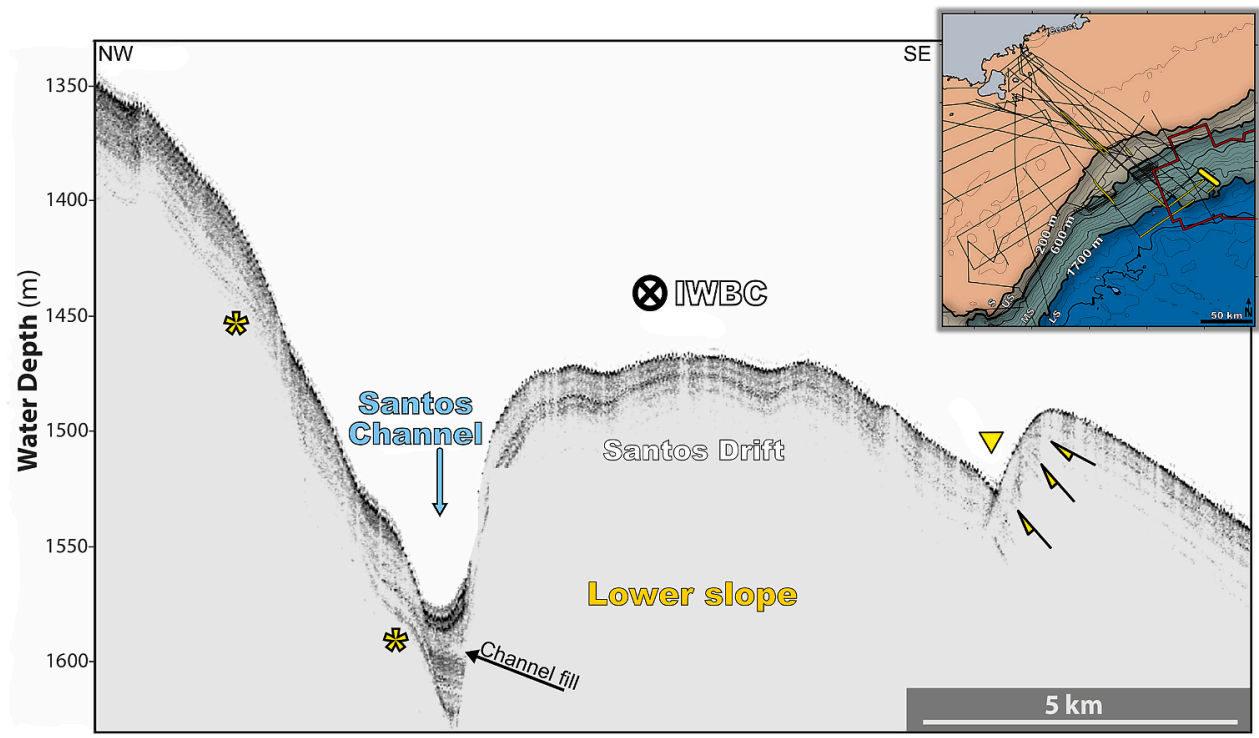

Fig. 9. Chirp sub-bottom profile providing a closer look to the Santos Channel and Drift, highlighting the steep middle slope, the partially infilled channel, and drift. Downfacing yellow arrows mark truncated layers, the yellow triangle marks a surface depression, and asterisks mark undulating reflections. IWBC flows to the northeast. Location is highlighted in yellow on the inset map and Fig. 1b. (For interpretation of the references to colour in this figure legend, the reader is referred to the web version of this article.) deepening from $\sim 1570$ to 1760 accompanied by a channel widening from $\sim 2.5$ to $\sim 4 \mathrm{~km}$. Its steep ( $>4^{\circ}$ ) western flank exhibits erosional truncation, while its equivalently steep eastern flank (Fig. 9) is cut by numerous localized slides (Fig. 7).

\subsubsection{Lower slope (1700 mbsl-deeper)}

Multichannel seismic reflection data show that the Santos Channeland-Drift System, as defined by Duarte and Viana (2007), occurs above the Cabo Frio fault and an attached salt diapir (Figs. 2, 10) and records a long-term lateral migration of channels, evidenced by the location of their thalwegs and intermediate mounds (white circles and

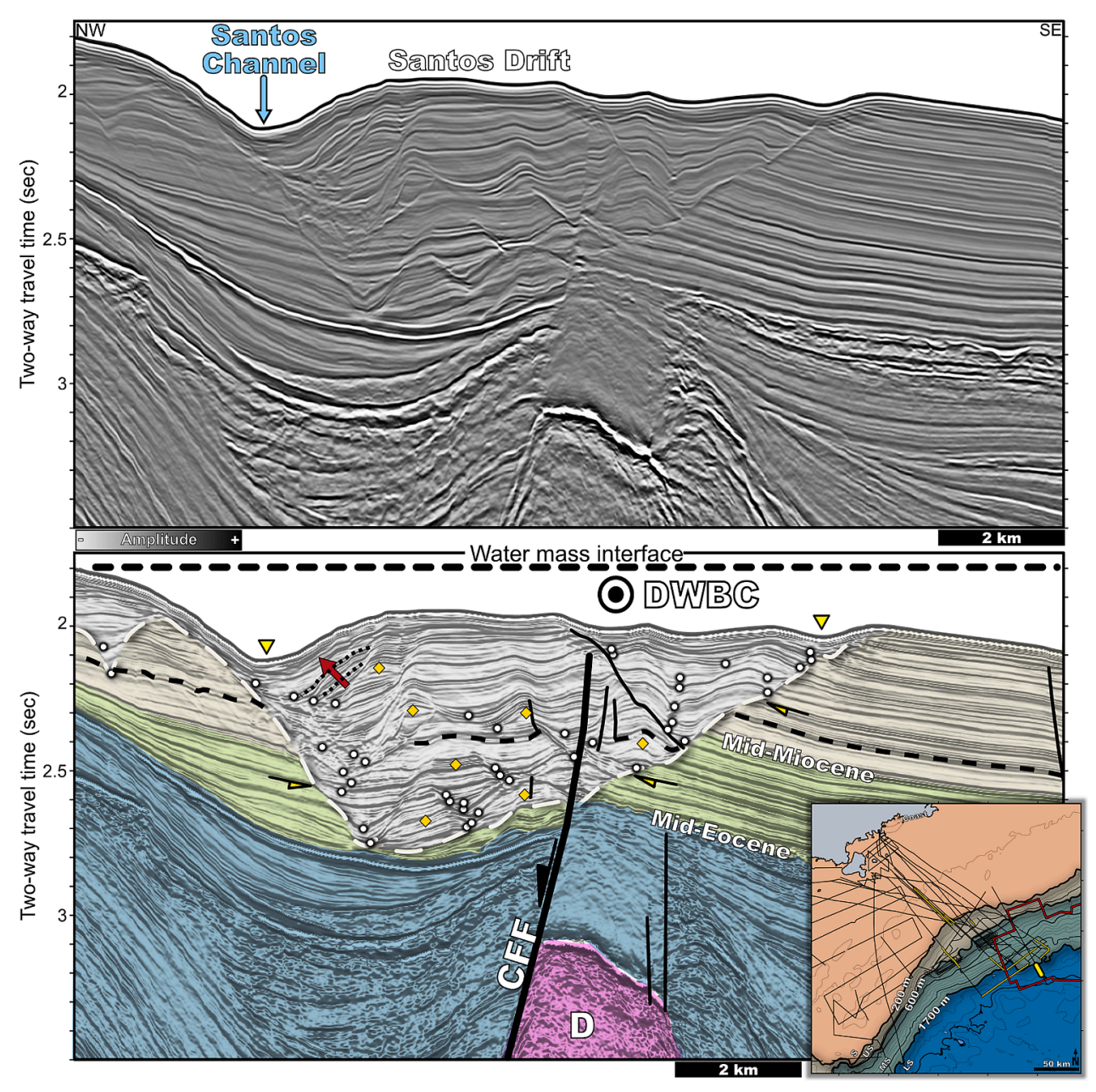

Fig. 10. Time-migrated multichannel seismic reflection profile crossing the Santos Channel and Drift (Santos Channel complex), presented in grayscale amplitude attribute (a) and blackwhite amplitudes with colored interpretation (b). Location is highlighted in yellow on the inset map and Fig. 2b. Yellow triangles - surface depressions, rhombi - drifts, white circles - thalweg of paleo depressions (contouritic channels). Red arrow and dashed black lines mark the landward progradation of contourite drifts below the modern Santos Channel. A white dashed line marks the lower limit of the Santos Channel complex. A thick black line and adjacent black arrow marks the Cabo Frio Fault (CFF), which bounds a subsurface diapir (D). Thin black lines mark faults. (For interpretation of the references to colour in this figure legend, the reader is referred to the web version of this article.) 


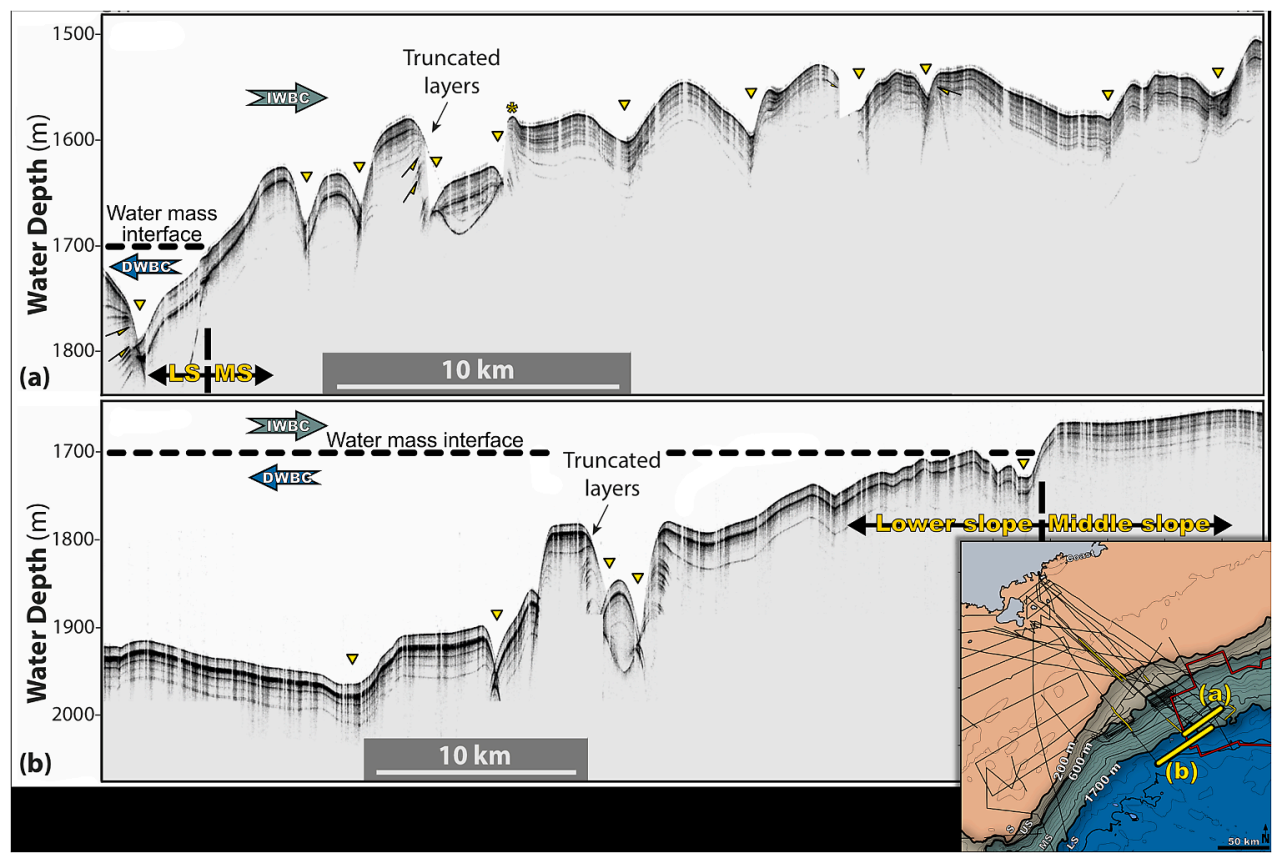

Fig. 11. Two along-slope Chirp sub-bottom profiles crossing the middle to lower slope boundary (MS and LS in (a)) below the direction reversal between IWBC and DWBC bottom currents. Both profiles exhibit an irregular seafloor morphology with relief differences of tens of meters between depressions (triangles) and intermediate mounds. Note the truncated reflectors on the mound flanks (yellow arrows) that, in places, curve away from the depression (asterisk). Location is highlighted in yellow on the inset map and Fig. 1b. (For interpretation of the references to colour in this figure legend, the reader is referred to the web version of this article.)

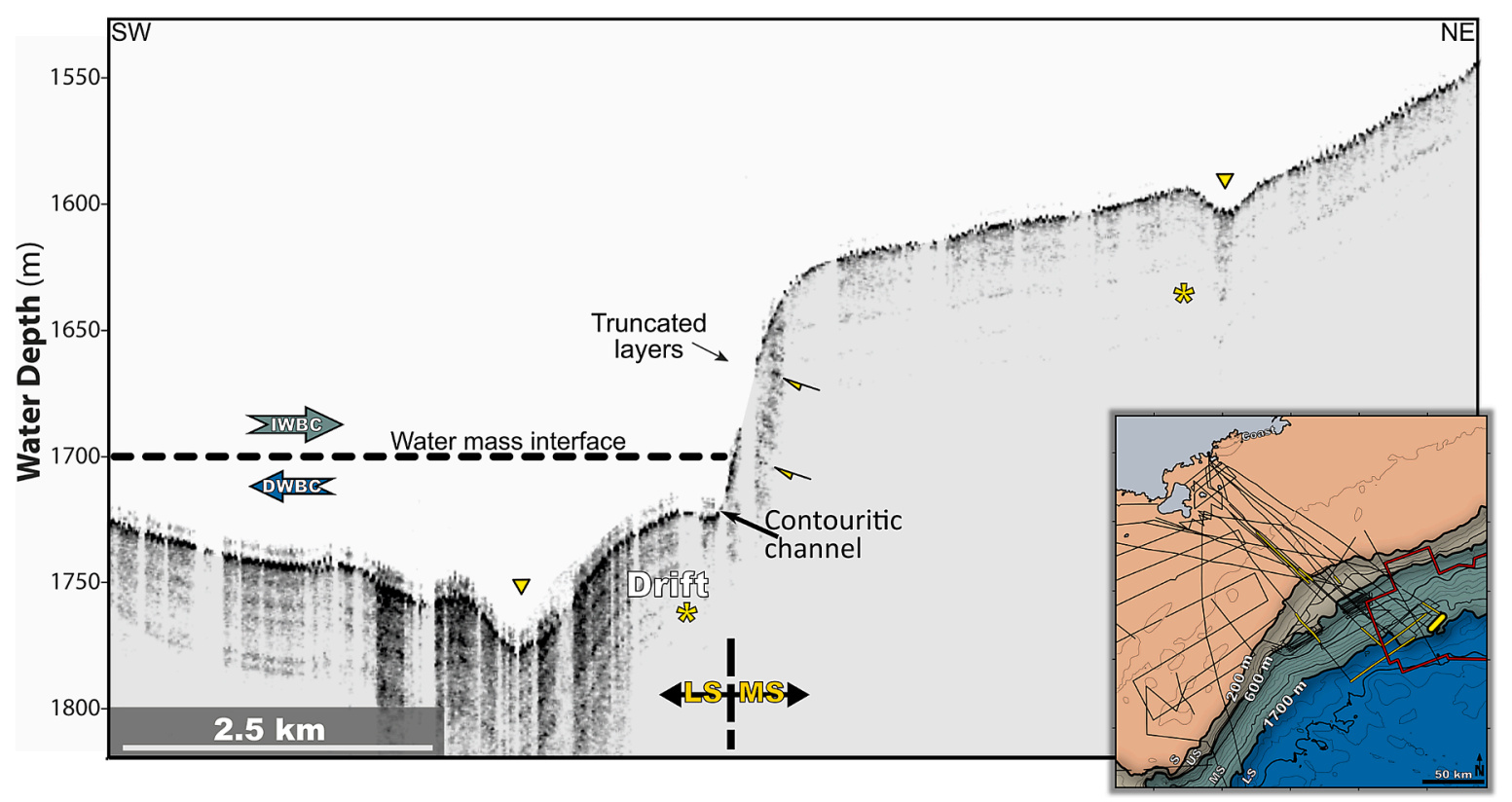

Fig. 12. Chirp sub-bottom profile crossing the middle to lower slope transition (MS and LS), below the direction reversal between the IWBC and DWBC bottom currents. A contouritic channel and drift developed along a steep $>50 \mathrm{~m}$ high slope, showing truncated reflections (yellow arrows). Location is highlighted in yellow on the inset map and Fig. 1b. (For interpretation of the references to colour in this figure legend, the reader is referred to the web version of this article.)

yellow rhombi in Fig. 10b).

The lower slope extends seaward from the Santos Channel-and-Drift System toward the deeper ocean (Figs. 7 to 12 ). It exhibits a $\sim 0.5^{\circ}$ gradient, which averages over a series of stratified mounds and kilometer-scale arc-shaped scars (Fig. 7). The arc-shaped scars vertically protrude the average relief by tens of meters (some exceeding $100 \mathrm{~m}$ ), while their tangents point mostly toward the Santos Channel (Fig. 7). The subsurface of the Santos Drift shows a general sub-parallel stratification, with some intercalations of undulated facies (Fig. 9). Unlike the other domains, the mounds and depressions are not separated by flat morphologies.

Seaward of the Santos Drift, numerous depressions oriented orthogonal to the slope consist of elongated fault-induced valleys that bound localized smooth-relief mini-basins (Fig. 7). These depressions exhibit erosional truncations at their flanks and separate diverse mounds (Figs. 11, 12).

\subsection{Hydrographic simulation}

Results of the LLC2160 simulation yield the classic baroclinic western boundary current system off Southeast Brazil. The simulation indicates that the annual-mean $0.03 \mathrm{~m} \mathrm{~s}^{-1}$ along-track flow is slow and negligible relative to the dominant along-margin component (Fig. 2b): In the upper $400 \mathrm{mbsl}$, the $100-\mathrm{km}$ wide Brazil Current (BC) flows 
southwestward with core velocities of $\sim-0.25 \mathrm{~m} \mathrm{~s}^{-1}$ at the ocean surface (flowing to the southwest). Below $400 \mathrm{mbsl}$, the $\sim 30-\mathrm{km}$ wide Intermediate Western Boundary Current (IWBC) flows in the opposite direction (i.e., northeast). Its core velocity of $0.125 \mathrm{~m} \mathrm{~s}^{-1}$ centers around 800 mbsl (between $\sim 600-1000 \mathrm{mbsl}$, Fig. 2b). At greater depths, the simulation shows an inversion into a mild southwest flow with an average velocity $\sim 0.075 \mathrm{~m} \mathrm{~s}^{-1}$.

\section{Discussion}

Results of this study point to a lasting imprint of the Subtropical Gyre flow on the morphology of the South Atlantic margin (Fig. 2b). Deep seismic data indicate that the margin morphology developed primarily due to the bottom current dynamics across the shelf, upper and middle slope, accompanied by localized influences of fluid flows (black arrows in Fig. 2a; pink shading in Fig. 6). The influence of deeper, salt-related structures occurs at greater depths beyond the Albian Gap (Figs. 2b, 7, 10). The seafloor morphology and subsurface data show the bottom currents molded the Santos margin relief during sub-recent and geologic times. The oceanographic water masses and their opposing flow indicate the connection between the morphologies and the present-day geostrophic bottom currents (Fig. 2b). Indeed, there is an agreement between the results of the LLC2160 simulation with the morphology and sedimentary patterns on the outer shelf and upper to middle slope, with the stronger velocities occurring on the outer shelf (BC) and on the interval between 800 and 1200 mbsl (the core of the AAIW).

\subsection{Significance of outer shelf-upper slope contouritic patterns}

At the seismic scale, the core of the $\mathrm{BC}$ has been associated with the deposition of a clinoform along the outer shelf-upper slope (Fig. 2; Schattner et al., 2018). On the shelf, the meandering pattern of the BC flow favored sediment removal on the outer shelf and transport toward the upper slope, leading to the formation of clinothems. We assume that spatial and temporal variations in the velocity and path of the BC altered the sediment supply from the shelf to the upper slope, and therefore the formation of the clinothems was not constant over time. This assumption is based on the alteration of deposition to erosion at the shallow subsurface of the shelf, as exhibited by the truncated reflections (Figs. 3, 4) and the filled paleo-channels (Fig. 4c).

The outer shelf escarpment (Fig. 4b) has been previously interpreted as the Last Glacial Maximum (LGM) lowstand shoreline (Reis et al., 2013). Seaward, the irregular geomorphological pattern exhibited by the outer shelf can be partially attributed to the occurrence of carbonate bioconstructions (Figs. 3, 4; Figueiredo and Tessler, 2004; Reis et al., 2013). The asymmetric patterns exhibited by some of the outer shelf carbonate mounds would be compatible with bedforms. Both bioaccumulation and bedform formation can be linked to stillstands during the postglacial transgression; bedform development could indicate reworking processes of paleo-shorelines; and subsequent covering by carbonates that enhances preservation (Kowsmann and Costa, 1974; Kowsmann and Costa, 1979).

The wide shelf to upper slope transition is characterized by marginparallel channels and escarpments related to erosional surfaces. These morphologies are interpreted to result from ongoing reworking by strike-parallel bottom currents of the BC (Figs. 1-4 Viana et al., 2002). This current-seafloor interaction corresponds with the definition of a shallow-water contourite system (e.g., (Verdicchio and Trincardi, 2008)). This shallow-water contourite system is equivalent in depths and appearance to the nearby Campos Basin, upstream of the BC (Fig. 1) (e.g., Viana et al., 1998a; Viana et al., 1998b).

The Santos shallow-water contourites described here are sedimentdepleted compared to equivalent contourites worldwide (e.g., in the Baltic Sea; Sivkov et al., 2002; in the Mediterranean Sea; Verdicchio and Trincardi, 2008) since local terrestrial sources do not feed them (e.g., de Mahiques et al., 2020). Hence, we attribute the depositional bedforms to localized transitions in the flow velocity and orientation (e.g., meandering). This pattern contrasts with other areas, which show more developed contouritic deposits, such as channel-related drifts (Sivkov et al., 2002) or mud-dominated sediment drifts (either sheeted or elongated), particularly documented in the Mediterranean Sea (Verdicchio and Trincardi, 2008; Vandorpe et al., 2011; Pepe et al., 2018; Martorelli et al., 2021). We relate the poor development of shallow-water contourites in the study area to the limited and distant sediment supply (e.g., Schattner et al., 2019) and due to the occurrence of wide shelves. Additionally, shallow-water contourites are usually fostered by interactions between currents and outstanding morpho-bathymetric features, such as faults or straits (Vandorpe et al., 2011; Pepe et al., 2018), which are absent in the study area.

At the upper slope, channel migration toward shallower areas (Fig. 4) indicates lateral (landward) translations of BC filaments in response to sea-level rise from the LGM until the present-day highstand conditions. Similar, yet opposite, translations were previously reported regarding the last lowstand. Coupled productivity increase and temperature decrease during the LGM have been related to the seaward BC shift toward the outer shelf (de Mahiques et al., 2007; Nagai et al., 2010).

\subsection{Effects of current reversal and the IWBC}

The reversal between the southwest-flowing BC and the northeastflowing IWBC generated the thinning of clinothems at the base of the upper slope (Figs. 5, 6a) and its culmination at a strip of rugged terrain (Fig. 7). Clinoform thinning is interpreted as the result of a decrease in sediment supply representing the transition to a different, less prolific source since the sediments are arriving almost exclusively via contour currents. The spatial coincidence of the rugged terrain strip with the subsurface indications for fluid/gas percolation with the BC-IWBC current reversal (Figs. 2b, 6, 7) may result from negligible flow velocities of water, as shown in the LLC2160 simulation. This quasi-stable zone lacks sediment deposition, facilitates mound buildups, and may also host percolation-related carbonate mounds, similar to its neighboring region of the Alpha Crucis ridge, which is located $\sim 60 \mathrm{~km}$ southwest of the study area at around the same water depths ( $\sim 400$ to $700 \mathrm{mbsl}$; $44.55^{\circ} \mathrm{W}, 24.95^{\circ} \mathrm{S}$; Maly et al., 2019).

The low-lying upper slope relief development resembles contourite terrace geomorphologies formed on the seafloor underlying an interface between water masses. For example, the La Plata contourite Terrace was identified off the Rio de la Plata River in the northern Argentinian margin, at a similar $\sim 500$ mbsl depth as the study area (Preu et al., 2013; Hernández-Molina et al., 2016). Erosion of the La Plata Terrace was associated with the turbulence in the interface between the superficial and the intermediate water masses in the Argentinian margin (Preu et al., 2013).

The larger-scale subsurface geometry in the middle slope at water depths higher than $600 \mathrm{~m}$ would indicate an overall low depositional rate that formed a thin and smoothed-surface sheeted contourite (ShC in Fig. 7) seaward of the shelf-edge clinoform (section above the thick dashed black line in Fig. 2a). This thickness difference would indicate the existence of two separate sediment delivery systems guided by the IWBC and the BC. Shallow subsurface data would indicate an intensification of bottom current reworking under a low sedimentation regime. The elongated depressions following the strike of the middle slope (Fig. 7) are interpreted as contourite channels formed under the IWBC (yellow triangles in Figs. 6c, 8). Their accompanying mounds are interpreted as contourite drifts, while their underlying undulating reflectors (yellow asterisks in Figs. 6c, 8) indicate that the contourites developed through time while remaining stationary.

\subsection{Role of salt tectonics below the IWBC-DWBC transition}

The shift in seafloor morphology and subsurface stratigraphy 
observed at the Santos Channel-and-Drift System, initially defined by Duarte and Viana (2007), stems from a deep-rooted player - salt tectonics. Landward of the channel, the Upper and Middle Slope are located above the 'Albian Gap' of the subsurface salt unit (Fig. 2; e.g., Guerra and Underhill, 2012). The distal Middle Slope overlays the Cabo Frio fault and the diapirs to the east. Seismic data support a composite origin for the Santos Channel-and-Drift System, in which both tectonic and sedimentary factors have been involved. On the one hand, the system developed through several generations since the Miocene, while its course maintained the same location above the Cabo Frio Fault and its associated diapir (Figs. 2, 10). In addition, contourite sedimentation patterns have also been involved in developing the system (Duarte and Viana, 2007).

The analyzed seismic data corroborate the occurrence of contouritic processes, as the shallowing and narrowing of the channel to the northeast have been driven mainly by the lateral migration of contourite channels and drifts and the occurrence of landward-directed progradation characteristic of sediment drifts (Fig. 7). However, there are also recent signs of gravity-driven processes in the system. For example, abundant arc-shaped depressions are recognized both in bathymetric (Fig. 7) and sub-bottom data (Fig. 11) over the present-day elongated bulge of the Santos Drift developed above the paleo courses of the Santos Channel (Figs. 7, 9, 10). These arc-shaped depressions are interpreted as localized rotational slides that form arc-shaped scars while progressing down-dip toward the Santos Channel (Fig. 7). It is reasonable to assume that these arc-slides, which may form escarpments tens of meters deep, redirected seafloor currents. The currents that flowed along the slides further eroded the escarpments and maintained their steepness (Fig. 11).

These observations would agree with a decreased activity through time of the Santos Channel Sedimentary System since contouritic processes seem to have been partially substituted by mass movements around the main channel. Indeed, the present-day channel occurs in the area of influence of the interface between the IWBC and the DWBC (Figs. 2, 10), where the IWBC exhibits a significant decrease in alongtrack velocities (Fig. 2b) below the middle slope where several contourite channels indicate relatively fast seafloor currents (Fig. 7).

Seaward of the Santos Sedimentary System, salt tectonics remains a dominant factor at the lower slope, yet its effect takes a different shape. The elongated extensional valleys developed above subsurface salt walls (Fig. 2) divide between mini-basins (e.g., Harding and Huuse, 2015; Duffy et al., 2017; Jackson and Hudec, 2017). Similar to the arc-slides, the elongated valleys also attracted and detoured the seafloor currents that passed their location and maintained the steep escarpments (Fig. 12). However, the relatively low flow velocities (Fig. 2b) resulted in mild contourite drift deposits (Fig. 12).

\section{Conclusions}

Due to the differences between the wind-driven Subtropical Gyre and Meridional Overturning Circulation in the South Atlantic, the water column masses flow along the Santos margin in opposing directions. In this margin, bottom current dominance on recent sedimentation patterns is also favored by a negligible terrestrial sediment supply to the margin. As a result, the study area provides a unique location for studying the morpho-sedimentary imprint of a counter-current flowing at mid-water depths, for elucidating the spatial variability of shallow to deep-water contourite systems, and the interaction of contouritic processes with salt tectonics and mass movements in deep slope settings.

A shallow-water contourite system is composed of depositional and erosional features on the outer shelf. These form a clinoform that thins toward the edge of the upper slope. These morphologies are attributed to the southward flow of the Brazil Current (BC) that supply allochthonous sediments, distribute them on the outer shelf and upper slope, and erodes the seafloor.

At the interface between the $\mathrm{BC}$ and its underlying and opposing northeast flowing Intermediate Western Boundary Current (IWBC, $\sim 600 \mathrm{~m}$ ), sedimentation ceases, the seafloor is rugged, and fluid/gas seepage is observed. Sheeted contourites over the middle slope are associated with the IWBC flow.

The middle slope smooth morphology is interrupted by the slopeparallel Santos Channel at the transitional depth between the IWBC and the underlying Deep Water Brazil Current (DWBC). Data show that the Santos Channel formation relates to deep-rooted salt tectonics and the prominent Cabo Frio Fault. The channel captures and directs the bottom currents, which in turn rework its surface expression.

Further basinward, the lower slope shows the dominant imprint of salt tectonics since this domain is located above diapirs. Bottom currents of the DWBC are directed by elongated, fault-related depressions that bound subsurface diapir-related mini-basins.

\section{Data availability statement}

Multichannel data were provided by the Brazilian National Agency of Petroleum, Natural Gas, and Biofuels solely for educational use and cannot be shared with third parties. Shallow, $3.5 \mathrm{kHz}$ chirp lines will be available at Mendeley (doi: 10.17632/mt95zwr325.1).

\section{Declaration of Competing Interest}

The authors declare not to have any conflict of interest, either commercial or non-commercial.

\section{Acknowledgments}

The authors are indebted to the crew and researchers of R/V Alpha Crucis, ¡who participated in the PASI, MUDBELTS II, TALUDE, and NAPGEOSEDEX pcruises. Financial support for the cruises was provided by the São Paulo ¡Science Foundation (FAPESP) (grants 2010/06147-5, 2014/08266-2, and やや2015/17763-2). ACBV acknowledges FAPESP (grant 2020/03363-0). M. M. de Mahiques acknowledges the National Council of Scientific and Technological pDevelopment (CNPq, grant 300962/2018-5). F.J. Lobo acknowledges the $\gg$ Brazilian program "Ciência sem Fronteiras" funded by CNPq, enabling him to ¡conduct several research stages as "Pesquisador Visitante Especial" at the やInstituto Oceanográfico, Universidade de São Paulo, under project number $\gg$ †01041/2014-0. The partnership between M. M. de Mahiques and U.Schattner is granted by FAPESP (2019/06250-5). U. Schattner acknowledges Schlumberger-Petrel for providing academic licenses that enabled the interpretation of seismic reflection data. The authors acknowledge Dr. Sara Rodrigues (Royal Holloway University of London) and two other anonymous reviewers for their contributions to the manuscript.

\section{References}

Almeida, F.F.M., Carneiro, C.D.R., 1998. Origem e evolução da Serra do Mar. Brazilian J. Geol. 28, 135-150.

Alves, T.M., Fetter, M., Lima, C., Cartwright, J.A., Cosgrove, J., Gangá, A., Queiroz, C.L., Strugale, M., 2017. An incomplete correlation between pre-salt topography, top reservoir erosion, and salt deformation in deep-water Santos Basin (SE Brazil). Mar. Pet. Geol. 79, 300-320.

Amante, C., Eakins, B., 2009. ETOPO1 1 Arc-Minute Global Relief Model: Procedures, Data Sources and Analysis, NOAA Technical Memorandum NESDIS NGDC-24. NOAA, Boulder, CO, p. 25.

Assireu, A.T., Dauhut, T., dos Santos, F.A., Lorenzzetti, J.A., 2017. Near-inertial motions in the Brazil current at $24^{\circ} \mathrm{S}-36^{\circ} \mathrm{S}$ : observations by satellite tracked drifters. Cont. Shelf Res. 145, 1-12.

Biló, T.C., da Silveira, I.C.A., Belo, W.C., de Castro, B.M., Piola, A.R., 2014. Methods for estimating the velocities of the Brazil Current in the pre-salt reservoir area off southeast Brazil (23॰ S-26॰ S). Ocean Dyn. 64, 1431-1446.

Boebel, O., Davis, R.E., Ollitrault, M., Peterson, R.G., Richardson, P.L., Schmid, C., Zenk, W., 1999. The intermediate depth circulation of the western South Atlantic. Geophys. Res. Lett. 26, 3329-3332.

Butler, L.W., 1970. Shallow Structure of the Continental margin, Southern Brazil and Uruguay. Geol. Soc. Am. Bull. 81.

Cainelli, C., Mohriak, W.U., 1999. Some remarks on the evolution of sedimentary basins along the eastern Brazilian continental margin. Episodes 222, 206-216. 
Caldas, M.F., Zalán, P.V., 2009. Reconstituição cinemática e tectono-sedimentação associada a domos salinos nas águas profundas da Bacia de Santos, Brasil. Boletim de Geociências da Petrobrás 17, 227-248.

Cogné, N., Gallagher, K., Cobbold, P.R., Riccomini, C., Gautheron, C., 2012. Post-breakup tectonics in Southeast Brazil from thermochronological data and combined inverseforward thermal history modeling. J. Geophys. Res. Solid Earth 117, B11413.

de Mahiques, M.M., Sousa, S.H.M., Burone, L., Nagai, R.H., Silveira, I.C.A., Soutelino, R. G., Ponsoni, L., Klein, D.A., 2011. Radiocarbon geochronology of the sediments of the São Paulo Bight (Southern Brazilian upper margin). An. Acad. Bras. Cienc. 83, 817-834.

de Mahiques, M.M., Tessler, M.G., Ciotti, A.M., Silveira, I.C.A., Sousa, S.H.M., Figueira, R.C.L., Tassinari, C.C.G., Furtado, V.V., Passos, R.F., 2004. Hydrodynamically driven patterns of recent sedimentation in the shelf and upper slope off Southeast Brazil. Cont. Shelf Res. 24, 1685-1697.

de Mahiques, M.M., Figueira, R.C.L., Sousa, S.H.d.M., Santos, R.F.d., Ferreira, P.A.d.L., Kim, B.S.M., Cazzoli y Goya, S., de Matos, M.C.S.N., Bícego, M.C., 2020. Sedimentation on the southern Brazilian shelf mud depocenters: Insights on potential source areas. J. S. Am. Earth Sci. 100, 102577.

de Mahiques, M.M., Fukumoto, M.M., Silveira, I.C.A., Figueira, R.C.L., Bícego, M.C., Lourenço, R.A., Sousa, S.H.M., 2007. Sedimentary changes on the Southeastern Brazilian upper slope during the last 35,000 years. An. Acad. Bras. Cienc. 79, $171-181$.

de Mahiques, M.M., Schattner, U., Lazar, M., Sumida, P.Y.G., Souza, L.A.P., 2017. An extensive pockmark field on the upper Atlantic margin of Southeast Brazil: spatial analysis and its relationship with salt diapirism. Heliyon 3, e00257.

Demercian, S., Szatmari, P., Cobbold, P.R., 1993. Style and pattern of salt diapirs due to thin-skinned gravitational gliding, Campos and Santos basins, offshore Brazil. Tectonophysics 228, 393-433.

Dias de Araujo, L., Lobo, F.J., de Mahiques, M.M., 2021. The imprint of sedimentary processes in the acoustic structure of deposits on a current-dominated continental shelf. J. S. Am. Earth Sci. 105.

Duarte, C.S.L., Viana, A.R., 2007. Santos Drift System: stratigraphic organization and implications for late Cenozoic palaeocirculation in the Santos Basin, SW Atlantic Ocean. Geol. Soc. Lond., Spec. Publ. 276, 171-198.

Duffy, O.B., Fernandez, N., Hudec, M.R., Jackson, M.P.A., Burg, G., Dooley, T.P., Jackson, C.A.L., 2017. Lateral mobility of minibasins during shortening: Insights from the SE Precaspian Basin, Kazakhstan. J. Struct. Geol. 97, 257-276.

Fernandes, A.M., da Silveira, I.C.A., Calado, L., Campos, E.J.D., Paiva, A.M., 2009. A twolayer approximation to the Brazil Current-Intermediate Western Boundary Current System between $20^{\circ} \mathrm{S}$ and $28^{\circ} \mathrm{S}$. Ocean Model 29, 154-158.

Figueiredo, A.G., Tessler, M.G., 2004. Topografia e composição do substrato marinho da região sudeste-sul do Brasil. Instituto Oceanográfico - USP, São Paulo.

Gamboa, L.A.P., Rabinowitz, P.D., 1981. The Rio Grande fracture zone in the western South Atlantic and its tectonic implications. Earth Planet. Sci. Lett. 52, 410-418.

Gomes, P.O., Viana, A.R., 2002. Contour currents, sediment drifts and abyssal erosion on the northeastern continental margin off Brazil. Geol. Soc. Lond. Mem. 22, 239-248.

Guerra, M.C.M., Underhill, J.R., 2012. Role of halokinesis in controlling structural styles and sediment dispersal in the Santos Basin, offshore Brazil. Geol. Soc. Lond., Spec. Publ. 363, 175-206.

Hanebuth, T.J.J., Lantzsch, H., Nizou, J., 2015. Mud depocenters on continental shelves Appearance, initiation times, and growth dynamics. Geo-Mar. Lett. 35, 487-503.

Harding, R., Huuse, M., 2015. Salt on the move: Multi stage evolution of salt diapirs in the Netherlands North Sea. Mar. Pet. Geol. 61, 39-55.

Hernández-Molina, F.J., Llave, E., Stow, D.A.V., 2008. Chapter 19 Continental Slope Contourites. In: Rebesco, M., Camerlenghi, A. (Eds.), Contourites. Elsevier, pp. 379-408.

Hernández-Molina, F.J., Soto, M., Piola, A.R., Tomasini, J., Preu, B., Thompson, P., Badalini, G., Creaser, A., Violante, R.A., Morales, E., Paterlini, M., De Santa Ana, H., 2016. A contourite depositional system along the Uruguayan continental margin: Sedimentary, oceanographic and paleoceanographic implications. Mar. Geol. 378, 333-349.

Hung Kiang, C., Kowsmann, R.O., Figueiredo, A.M.F., Bender, A., 1992. Tectonics and stratigraphy of the East Brazil Rift system: an overview. Tectonophysics 213, 97-138.

Jackson, M.P.A., Hudec, M.R., 2017. Seismic Interpretation of Salt Structures. In: Jackson, M.P.A., Hudec, M.R. (Eds.), Salt Tectonics. Cambridge University Press, Cambridge, pp. 364-398.

Kowsmann, R.O., Costa, M.P.A., 1974. Paleolinhas de costa na plataforma continental das regiões sul e norte brasileira. Revista Brasileira de Geociências 4, 215-222.

Kowsmann, R.O., Costa, M.P.A., 1979. Sedimentação quaternária da margem continental brasileira e das áreas adjacentes. Petrobrás (In Portuguese), Rio de Janeiro. 8, 1-55.

Kumar, N., Gambôa, L.A.P., 1979. Evolution of the São Paulo Plateau (southeastern Brazilian margin) and implications for the early history of the South Atlantic. Geol. Soc. Am. Bull. 90, 281-293.

Legeais, J.-F., Ollitrault, M., Arhan, M., 2013. Lagrangian observations in the Intermediate Western Boundary current of the South Atlantic. Deep-Sea Res. II Top. Stud. Oceanogr. 85, 109-126.

Locarnini, R.A., Mishonov, A.V., Baranova, O.K., Boyer, T.P., Zweng, M.M., Garcia, H.E., Reagan, J.R., Seidov, D., Weathers, K., Paver, C.R., Smolyar, I., 2018. World Ocean Atlas 2018, volume 1: Temperature. In: NOAA Atlas NESDIS 81. NOAA, Boulder.

Magalhães, F.C., Azevedo, J.L.L., Oliveira, L.R., 2017. Energetics of eddy-mean flow interactions in the Brazil current between $20^{\circ} \mathrm{S}$ and $36^{\circ} \mathrm{S}$. J. Geophys. Res. Oceans 122, 6129-6146.

Maly, M., Schattner, U., Lobo, F., Ramos, R.B., Dias, R.J., Couto, D.M., Sumida, P.Y., de Mahiques, M.M., 2019. The Alpha Crucis Carbonate Ridge (ACCR): Discovery of a giant ring-shaped carbonate complex on the SW Atlantic margin. Sci. Rep. 9, 18697.
Martorelli, E., Bosman, A., Casalbore, D., Chiocci, F., Conte, A.M., Di Bella, L., Ercilla, G., Falcini, F., Falco, P., Frezza, V., Gaglianone, G., Giaccio, B., Mancini, M., 2021. Midto-late Holocene upper slope contourite deposits off Capo Vaticano (Mediterranean Sea): High-resolution record of contourite cyclicity, bottom current variability and sandy facies. Mar. Geol. 431.

Meisling, K.E., Cobbold, P.R., Mount, V.S., 2001. Segmentation of an obliquely rifted margin, Campos and Santos basins, southeastern Brazil. AAPG Bull. 85, 1903-1924.

Menemenlis, D., Campin, J.-M., Heimbach, P., Hill, C., Lee, T., Nguyen, A., Schodlok, M., Zhang, H., 2008. ECCO2: High Resolution Global Ocean and Sea Ice Data Synthesis Mercator Ocean. Q. Newsl. 31, 13-21.

Milliman, J.D., 1978. Morphology and structure of upper continental margin off Southern Brazil. AAPG Bull. 62.

Modica, C.J., Brush, E.R., 2004. Postrift sequence stratigraphy, paleogeography, and fill history of the deep-water Santos Basin, offshore Southeast Brazil. AAPG Bull. 88, 923-945.

Mohriak, W.U., Macedo, J.M., Castellani, R.T., Rangel, H.D., Barros, A.Z.N., Latge, M.A. L., Ricci, J.A., Mizusaki, A.M.P., Szatmari, P., Demercian, L.S., Rizzo, J.G., Aires, J. R., 1995. Salt tectonics and structural styles in the deep-water province of the Cabo Frio region, Rio de Janeiro, Brazil. Salt Tectonics: A Global Perspective 65, 273-304.

Moreira, J.L.P., Madeira, C.V., Gil, J.A., Machado, M.A.P., 2007. Bacia de Santos. Boletim de Geociências da Petrobrás 15, 531-549.

Müller, T.J., Ikeda, Y., Zangenberg, N., Nonato, L.V., 1998. Direct measurements of western boundary currents off Brazil between $20^{\circ} \mathrm{S}$ and $28^{\circ} \mathrm{S}$. J. Geophys. Res. Oceans 103, 5429-5437.

Nagai, R.H., Sousa, S.H.D.M.E., Lourenço, R.A., Bícego, M.C., de Mahiques, M.M., 2010. Paleoproductivity changes during the late Quaternary in the southeastern Brazilian upper continental margin of the Southwestern Atlantic. Braz. J. Oceanogr. 58, $31-41$.

NOAA, N.G.D.C., 2009. ETOPO1 1 Arc-Minute Global Relief Model. NOAA National Centers for Environmental Information.

Núñez-Riboni, I., Boebel, O., Ollitrault, M., You, Y., Richardson, P.L., Davis, R., 2005. Lagrangian circulation of Antarctic Intermediate Water in the subtropical South Atlantic. Deep-Sea Res. II Top. Stud. Oceanogr. 52, 545-564.

ODV, 2020. Ocean Data View. Afred Wegener Institut, Bremerhaven.

Pepe, F., Di Donato, V., Insinga, D., Molisso, F., Faraci, C., Sacchi, M., Dera, R., Ferranti, L., Passaro, S., 2018. Seismic stratigraphy of upper Quaternary shallowwater contourite drifts in the Gulf of Taranto (Ionian Sea, southern Italy). Mar. Geol. 397, 79-92.

Perez, J.A.A., Gavazzoni, L., de Souza, L.H.P., Sumida, P.Y.G., Kitazato, H., 2020. DeepSea Habitats and Megafauna on the Slopes of the São Paulo Ridge. SW Atlantic. Front. Marine Sci. 7, 572166.

Peterson, R.G., Stramma, L., 1991. Upper-level circulation in the South Atlantic Ocean. Prog. Oceanogr. 26, 1-73.

Preu, B., Hernández-Molina, F.J., Violante, R., Piola, A.R., Paterlini, C.M., Schwenk, T., Voigt, I., Krastel, S., Spiess, V., 2013. Morphosedimentary and hydrographic features of the northern argentine margin: the interplay between erosive, depositional and gravitational processes and its conceptual implications. Deep-Sea Res. I Oceanogr. Res. Pap. 75, 157-174.

Quirk, D.G., Schødt, N., Lassen, B., Ings, S.J., Hsu, D., Hirsch, K.K., Von Nicolai, C., 2012. Salt tectonics on passive margins: examples from Santos, Campos and Kwanza basins. Geol. Soc. Lond., Spec. Publ. 363, 207-244.

Rebesco, M., Hernandez-Molina, F.J., Van Rooij, D., Wahlin, A., 2014. Contourites and associated sediments controlled by deep-water circulation processes: State-of-the-art and future considerations. Mar. Geol. 352, 111-154.

Reis, A.T., Maia, R.M.C., Silva, C.G., Rabineau, M., Guerra, J.V., Gorini, C., Ayres, A., Arantes-Oliveira, R., Benabdellouahed, M., Simões, I., Tardin, R., 2013. Origin of step-like and lobate seafloor features along the continental shelf off Rio de Janeiro State, Santos basin-Brazil. Geomorphology 203, 25-45.

Rocha, C.B., Gille, S.T., Chereskin, T.K., Menemenlis, D., 2016. Seasonality of submesoscale dynamics in the Kuroshio Extension. Geophys. Res. Lett. 43, 11,304$311,311$.

Ryan, W.B.F., Carbotte, S.M., Coplan, J.O., O'Hara, S., Melkonian, A., Arko, R., Weissel, R.A., Ferrini, V., Goodwillie, A., Nitsche, F., Bonczkowski, J., Zemsky, R., 2009. Global Multi-Resolution Topography synthesis. Geochem. Geophys. Geosyst 10, Q03014.

Schattner, U., Lobo, F.J., García, M., Kanari, M., Ramos, R.B., de Mahiques, M.M., 2018. A detailed look at diapir piercement onto the ocean floor: New evidence from Santos Basin, offshore Brazil. Mar. Geol. 406, 98-108.

Schattner, U., Lobo, F.J., López-Quirós, A., Passos Nascimento, J.L., Mahiques, M.M., 2020. What feeds shelf-edge clinoforms over margins deprived of adjacent land sources? An example from Southeastern Brazil. Basin Res 32, 293-301.

Schmid, C., Siedler, G., Zenk, W., 2000. Dynamics of Intermediate Water Circulation in the Subtropical South Atlantic. J. Phys. Oceanogr. 30, 3191-3211.

Shanmugam, G., 2017. The Contourite Problem. In: Mazumder, R. (Ed.), Sediment Provenance. Elsevier, Amsterdam, pp. 183-254.

Silveira, I.C.A., Calado, L., Castro, B.M., Cirano, M., Lima, J.A.M., Mascarenhas, A.D.S., 2004. On the baroclinic structure of the Brazil Current-Intermediate Western Boundary Current system at $22^{\circ}-23^{\circ} \mathrm{S}$. Geophys. Res. Lett. 31, L14308.

Sivkov, V., Gorbatskiy, V., Kuleshov, A., Zhurov, Y., 2002. Muddy contourites in the Baltic Sea: an example of a shallow-water contourite system. Geol. Soc. Lond. Mem. $22,121-136$.

Souza, R.B., Robinson, I.S., 2004. Lagrangian and satellite observations of the Brazilian Coastal Current. Cont. Shelf Res. 24, 241-262.

Steventon, M.J., Jackson, C.A.L., Hodgson, D.M., Johnson, H.D., 2020. Lateral variability of shelf-edge and basin-floor deposits, Santos Basin, offshore Brazil. J. Sediment. Res. 90, 1198-1221. 
Stow, D.A.V., Faugères, J.-C., Viana, A., Gonthier, E., 1998. Fossil contourites: a critical review. Sediment. Geol. 115, 3-32.

Stow, D.A.V., Hunter, S., WIilkinson, D., Hernandez-Molina, F.J., 2008. The nature of contourite deposition. In: Rebesco, M.C., Camerlenghi, A. (Eds.), Developments in Sedimentology. Elsevier, Amsterdam, pp. 143-156.

Stramma, L., England, M., 1999. On the water masses and mean circulation of the South Atlantic Ocean. J. Geophys. Res. Oceans 104, 20863-20883.

Szatmari, P., Guerra, M.C.M., Pequeno, M.A., 1996. Genesis of large counter-regional normal fault by flow of cretaceous salt in the South Atlantic Santos Basin, Brazil Geol. Soc. Lond., Spec. Publ. 100, 259-264.

Tallobre, C., Loncke, L., Bassetti, M.-A., Giresse, P., Bayon, G., Buscail, R., de Madron, X. D., Bourrin, F., Vanhaesebroucke, M., Sotin, C., 2016. Description of a contourite depositional system on the Demerara Plateau: Results from geophysical data and sediment cores. Mar. Geol. 378, 56-73.

Vandorpe, T.P., Van Rooij, D., Stow, D.A.V., Henriet, J.-P., 2011. Pliocene to recent shallow-water contourite deposits on the shelf and shelf edge off south-western Mallorca, Spain. Geo-Mar. Lett. 31, 391-403.

Verdicchio, G., Trincardi, F., 2008. Shallow-Water Contourites. In: Rebesco, M., Camerlenghi, A. (Eds.), Contourites. Elsevier, Amsterdam, pp. 409-433.

Viana, A.R., Faugeres, J.C., Kowsmann, R.O., Lima, J.A.M., Caddah, L.F.G., Rizzo, J.G, 1998a. Hydrology, morphology and sedimentology of the Campos continental margin, offshore Brazil. Sediment. Geol. 115, 133-157.
Viana, A.R., Faugères, J.C., Stow, D.A.V., 1998b. Bottom-current-controlled sand deposits - a review of modern shallow- to deep-water environments. Sediment. Geol. 115, 53-80.

Viana, A.R., De Almeida, W., De Almeida, C.W., 2002. Upper slope sands: late Quaternary shallow-water sandy contourities of Campos Basin, SW Atlantic margin. Geol. Soc. Lond. Mem. 22, 261-270.

Wilckens, H., Miramontes, E., Schwenk, T., Artana, C., Zhang, W., Piola, A.R., Baques, M., Provost, C., Hernández-Molina, F.J., Felgendreher, M., Spieß, V., Kasten, S., 2021. The erosive power of the Malvinas Current: Influence of bottom currents on morpho-sedimentary features along the northern Argentine margin (SW Atlantic Ocean). Mar. Geol. 439, 106539.

Williams, B.G., Hubbard, R.J., 1984. Seismic stratigraphic framework and depositional sequences in the Santos Basin, Brazil. Mar. Pet. Geol. 1, 90-104.

Zalan, P.V., Oliveira, J.A.B., 2005. Origem e evolução estrutural do Sistema de Riftes Cenozóicos do Sudeste do Brasil. Boletim de Geociências da Petrobrás 13, 269-300.

Zembruscki, S.G., 1979. Geomorfologia da margem continental sul brasileira e das bacias oceânicas adjacentes. In: Chaves, H.A.F. (Ed.), Geomorfologia da margem continental Brasileira e áreas oceânicas adjacentes. Petrobrás (In Portuguese), Rio de Janeiro, pp. 129-177. 